\title{
Transboundary ozone pollution across East Asia: daily evolution and photochemical production analysed by IASI + GOME2 multispectral satellite observations and models
}

\author{
Juan Cuesta $^{1}$, Yugo Kanaya ${ }^{2}$, Masayuki Takigawa ${ }^{2}$, Gaëlle Dufour ${ }^{1}$, Maxim Eremenko ${ }^{1}$, Gilles Foret ${ }^{1}$, \\ Kazuyuki Miyazaki ${ }^{2}$, and Matthias Beekmann ${ }^{1}$ \\ ${ }^{1}$ Laboratoire Inter-universitaire des Systèmes Atmosphériques (LISA), UMR7583, Universités Paris-Est Créteil et Paris \\ Diderot, CNRS, Créteil, France \\ ${ }^{2}$ Japan Agency for Marine-Earth Science and Technology, Yokohama, Japan
}

Correspondence: Juan Cuesta (cuesta@ lisa.u-pec.fr)

Received: 17 October 2017 - Discussion started: 18 October 2017

Revised: 2 May 2018 - Accepted: 3 May 2018 - Published: 6 July 2018

\begin{abstract}
We characterise a transboundary ozone pollution outbreak transported across East Asia in early May 2009 using new multispectral satellite observations of lowermost tropospheric ozone (located below $3 \mathrm{~km}$ altitude) in synergy with other satellite data and models. Our analysis is focused on the daily evolution of ozone pollution plumes initially formed over the North China Plain (NCP) and their transport pathways over northern China, Korea, Japan and the surrounding seas. A main aspect of the study is an estimation of the contribution of photochemical production of ozone during transport using the ratio of ozone to carbon monoxide enhancements with respect to background levels derived from satellite data and also from chemistry-transport models.

A key contribution of the analysis is the use of new satellite data offering unprecedented skills to observe the horizontal distribution of lowermost tropospheric ozone over East Asia on a daily basis, with a multispectral approach called IASI + GOME2 (combining Infrared Atmospheric Sounding Interferometer observations in the IR and Global Ozone Monitoring Experiment-2 measurements in the UV). These satellite observations are in good agreement with ozonesondes, with low mean biases $(3 \%)$, a precision of about $16 \%$, a correlation coefficient of 0.85 and practically the same standard deviation for a comparison based on 2 years of data from 46 launching stations distributed worldwide, during all seasons. A similar agreement is also found over East Asia. Moreover, IASI + GOME2 offers a unique capacity for observing the evolution of near-surface ozone during pollution outbreaks (with $5 \%$ bias and 0.69 correlation), according to
\end{abstract}

a comparison with surface in situ measurements during two major ozone events over several Japanese islands. Singleband ozone retrievals, such as those from IASI in the thermal infrared, do not capture such variability.

Using IASI + GOME2, we show that (i) ozone pollution plumes are transported by an anticyclonic circulation around the Yellow Sea from the NCP to northern China, Korea and Japan, collocated with carbon monoxide plumes; (ii) over northern China the plume splits into two pollution filaments with one mixing with freshly emitted pollutants; and (iii) ozone is produced every day of the event, accounting for an enhancement in concentration during transport across East Asia of up to $\sim 84 \%$ with respect to that produced over NCP. This estimation is done according to monotonically increasing values during 7 days of the ratio of ozone to carbon monoxide enhancements within the transported pollution plumes from about $\sim 0.25$ over the NCP to $\sim 0.46$ over the Pacific south of Japan.

\section{Introduction}

Air pollution is now the world's largest single environmental health risk, causing 7 million premature deaths worldwide every year (Lelieveld et al., 2015; World Health Organization - WHO, 2016). About 4.3 million of these deaths are related to ambient air pollution, from which 2.6 million deaths per year occur over Southeast and East Asia as a result of 
exposure to the world's largest air-pollution-related burden (WHO, 2016). East Asia, and in particular China, experienced rapid economic growth (up to a factor of 40 of the gross domestic product since the 1980s) and extensive urbanisation during the last decades. Accordingly, anthropogenic pollutant emissions have largely increased, making China one of the largest pollution source regions in the world ( $\mathrm{Lu}$ et al., 2011; Wang et al., 2013). In the main Chinese megacities, ambient concentrations of the most harmful pollutants, such as tropospheric ozone $\left(\mathrm{O}_{3}\right)$ and particulate matter $(\mathrm{PM})$, largely exceed the thresholds recommended by WHO (Chai et al., 2014). Air pollution originating from East Asia is also a worldwide-shared concern. It can be transported and undergo chemical transformations far beyond country boundaries within a day and around the hemisphere within 1 or 2 weeks, having a significant impact on the budget of tropospheric pollutants at the intercontinental scale (e.g. Lin et al., 2010). For example, current trends of ozone concentrations at the surface over Japan show a significant increase, despite strong local controls of pollution emissions in the last decades and probably related to transboundary transport (Akimoto et al., 2015). Similarly, transcontinental transport of Asian pollution probably explains the absence of reduction in ozone background levels over the United States or Europe, despite local efforts for reducing the emissions of its precursors (e.g. Dentener et al., 2010; Verstraeten et al., 2015).

The dramatic damages caused by East Asian air pollution at regional and intercontinental scales necessitate thorough monitoring of pollutant emissions both near the sources and downwind from these regions, where secondary pollutants are photochemically produced. However, the record of surface network observations of air pollution over China is very limited, being openly available only since 2013 (Wang et al., 2014). On the other hand, forecasting East Asian air pollution with chemistry-transport models is hampered by two factors: insufficient surface observations for validating the simulations (particularly over the East China Sea) and the lack of precision of the emission inventories, which are unable to reflect the rapid changes in the Chinese economy and the complexity of their emissions (Wang et al., 2015).

Satellite observations offer great potential for filling the observational gap of air pollution over East Asia and overcome the limited spatial coverage of ground-based measurements. Nevertheless, measuring ozone pollution from space is a challenging issue. Standard single-band ozone retrievals cannot provide quantitative information at the planetary boundary layer (PBL); the lowest they can provide it is in the lower troposphere (LT, i.e. below $6 \mathrm{~km}$ altitude). Sensitivity to ozone for these retrievals essentially peaks in the free troposphere above the PBL, according to the available information on near-surface ozone. Space-borne spectrometers operating in the ultraviolet (UV), like OMI (Ozone Monitoring Instrument; Levelt et al., 2006) and GOME-2 (Global Ozone Monitoring Experiment-2; EUMETSAT, 2006), have been used to derive tropospheric ozone observations with sensitivity around 5-6 km altitude (e.g. Liu et al., 2010; Cai et al., 2012). Thermal infrared (IR) space-borne instruments, like IASI (Infrared Atmospheric Sounding Interferometer; Clerbaux et al., 2009) on board the MetOp satellites, have shown good performance for observing ozone in the lower troposphere, but with sensitivity peaking at $3 \mathrm{~km}$ altitude at the lowest (e.g. Eremenko el al., 2008; Dufour et al., 2012). Recently, a new multispectral approach called IASI + GOME2, combining IASI observations in the IR and GOME-2 measurements in the UV, allowed the first space-borne observation of the full horizontal structure and concentration of ozone plumes located near $2 \mathrm{~km}$ altitude, for a moderate European pollution outbreak (Cuesta et al., 2013). This approach offers the unique capacity to observe the horizontal distribution of ozone in the lowermost troposphere (LMT), hereafter defined as the atmospheric layer between the surface and $3 \mathrm{~km}$ above sea level (a.s.l.). Similarly, the multispectral combination of TES (Tropospheric Emission Spectrometer; Worden et al., 2007) and OMI measurements, respectively in the IR and UV, has also shown an enhancement of sensitivity below $700 \mathrm{hPa}$ (Fu et al., 2013), but with very limited horizontal coverage (pixels longitudinally spaced by about $2000 \mathrm{~km}$ on the same day). Multispectral synergisms are also implemented to retrieve other atmospheric species with enhanced near-surface sensitivity, such as carbon monoxide (CO). This is done with measurements in the thermal and near infrared from the Measurements Of Pollution In The Troposphere (MOPITT) instrument on board the Earth Observing System (EOS) Terra satellite (Worden et al., 2010). Recently, the Sentinel-5 Precursor (S5P) and Suomi National Polar-orbiting Partnership (SNPP) have successfully formed a satellite constellation, leading to a new opportunity to quantify the amounts of $\mathrm{CO}$ in the LMT on a global scale by combining the satellite measurements in the thermal and near IR respectively from the instruments SNPP Cross-track Infrared Sounder (CrIS) and S5P TROPOspheric Monitoring Instrument (TROPOMI). Fu et al. (2016) presented the methodology and characteristics of joint CrIS-TROPOMI CO profile retrievals, demonstrating the feasibility for extending the decadal record of MOPITT CO products (Worden et al., 2013).

Simultaneously monitoring several air pollutants may offer useful insights on the origin and evolution of ozone pollution. For example, high concentrations of both ozone and carbon monoxide suggest an anthropogenic origin of the air masses, as $\mathrm{CO}$ is a primary product of traffic and industrial emissions and is formed by oxidation of anthropogenic hydrocarbons. Its lifetime is about 2 months (e.g. Logan et al., 1981). Tropospheric ozone-enriched air masses with background concentrations of $\mathrm{CO}$ and low water vapour levels are probably related to downward transport from the stratosphere and the upper troposphere-lower stratosphere (UTLS) region. The ratio between the enhancements of $\mathrm{O}_{3}$ and $\mathrm{CO}$ with respect to the background levels allows examining the production of ozone from combustion by-products (nitrogen 
oxides $-\mathrm{NO}_{x}$; hydrocarbons; and $\mathrm{CO}$ ) by photochemical processing of air parcels during a few days to a week (e.g. Parrish et al., 1993; Chin et al., 1994; Mauzerall et al., 2000). This approach may however underestimate ozone production during transport since CO may not only be directly emitted but also produced by oxidation of hydrocarbons (Chin et al., 1994; Gao et al., 2005). This ratio has been mainly estimated using in situ measurements at several ground-based sites (Chin et al., 1994), from aircrafts (Price et al., 2004), model simulations (Maurezall et al., 2000) and in a few cases with satellite data mainly sensitive in the free troposphere (Zhang et al., 2006; Kim et al., 2013; Dufour et al., 2015). In addition, high abundances of ozone precursors, such as nitrogen dioxide $\left(\mathrm{NO}_{2}\right)$ and volatile organic compounds (VOCs) like formaldehyde $\left(\mathrm{CH}_{2} \mathrm{O}\right)$, may be linked to higher photochemical production of $\mathrm{O}_{3}$, depending on the regime of ozone atmospheric production (i.e. limited by the availability of $\mathrm{NO}_{x}$ or VOCs).

In the present paper, we characterise the daily evolution of a major ozone outbreak across East Asia in early May 2009, using the new multispectral satellite approach IASI + GOME2 in synergism with chemistry-transport and meteorological models as well as other observations $(\mathrm{CO}$, $\mathrm{NO}_{2}, \mathrm{CH}_{2} \mathrm{O}$ etc.). We present the first observational description of the transport pathways of ozone plumes from satellite measurements in the LMT (below $3 \mathrm{~km}$ altitude) over East Asia, and we analyse the processes controlling the lowermost tropospheric ozone burden during this event (i.e. photochemical production and downward transport from the stratosphere). Our study uses the ratio between the enhancements of $\mathrm{O}_{3}$ and $\mathrm{CO}$ to characterise the Lagrangian production of ozone during transport across East Asia, derived for the first time from ozone satellite data sensitive in the LMT. First, the paper presents the datasets used in the study and a quality assessment of the IASI + GOME2 ozone observations by comparing them with in situ measurements performed by ozonesondes and also by surface stations (Sect. 2). This comparison illustrates the unprecedented capacity of IASI + GOME2 to observe from space the variability of surface ozone concentrations. Section 3 describes the regional distribution of ozone plumes and the meteorological conditions during each day of the pollution outbreak. Then, we focus on the Lagrangian evolution of major ozone plumes, analysing the possible enhancement of ozone concentrations by photochemical production during transport (Sect. 4). A summary is provided in Sect. 5.

\section{Dataset description}

\subsection{Satellite observations of lowermost tropospheric ozone: IASI + GOME2}

The multispectral satellite approach IASI + GOME2 is designed for observing lowermost tropospheric ozone by syner- gism of thermal IR atmospheric radiances observed by IASI and UV earth reflectances measured by GOME-2. Both instruments are on board the MetOp satellite series (in orbit since 2006 and expected until 2022), and they both offer global coverage every day (for MetOp-A around 09:30 local time) with a relatively fine ground resolution $(12 \mathrm{~km}$ diameter pixels spaced by $25 \mathrm{~km}$ for IASI at nadir and ground pixels of $80 \mathrm{~km} \times 40 \mathrm{~km}$ for GOME-2). As described in detail by Cuesta et al. (2013), IASI + GOME2 jointly fits collocated IR and UV spectra for retrieving a single vertical profile of ozone for each pixel. The horizontal resolution corresponds to that of IASI, using for each pixel the UV measurements from the closest GOME-2 pixel (without averaging). Spectra and Jacobians in the IR and UV are respectively simulated by the KOPRA (Karlsruhe Optimized and Precise Radiative transfer Algorithm; Stiller et al., 2002) and VLIDORT (Vector Linearized Discrete Ordinate Radiative Transfer; Spurr, 2006) radiative transfer codes. The effects of clouds and aerosols are partially taken into account by iteratively adjusting offsets for each of the seven spectral microwindows (between 980 and $1070 \mathrm{~cm}^{-1}$ ) used in the IR and effective surface albedos and cloud fractions in the UV (two micro-windows between 290 and $345 \mathrm{~nm}$ ). Only measurements with cloud fractions below $30 \%$ are used (as determined by the FRESCO algorithm (Fast Retrieval Scheme for Clouds from the Oxygen A-band; Koelemeijer et al., 2001). Ozone profiles are retrieved by a constrained least squares fitting method using a Tikhonov-Phillips-type regularisation (Tikhonov, 1963). Constraint strengths vary with altitude and are optimised for enhancing sensitivity to lowermost tropospheric ozone while keeping acceptable total retrieval errors (in the order of $20 \%$ for the LMT).

Here, we use an updated version of the IASI + GOME2 product, with only minor changes with respect to that of Cuesta et al. (2013). Ozone profiles are retrieved at the vertical grid between the surface and $60 \mathrm{~km}$ a.s.l., with steps of 1 , 2 and $5 \mathrm{~km}$ respectively below $26 \mathrm{~km}$ a.s.1., between 26 and $30 \mathrm{~km}$ a.s.l. and above $30 \mathrm{~km}$ a.s.l.. Three a priori ozone profiles derived from the climatology of McPeters et al. (2007) are used, corresponding to the average over $20-30^{\circ} \mathrm{N}, 30$ $60^{\circ} \mathrm{N}$ and $60-90^{\circ} \mathrm{N}$, representative of tropical, mid-latitude and polar conditions. These three a priori profiles are used for IASI pixels with tropopause heights (determined by the temperature vertical profile) above 14 , between 14 and $9 \mathrm{~km}$, and below $9 \mathrm{~km}$ respectively.

IASI + GOME2 products include vertical profiles of ozone, partial columns, averaging kernels (representing sensitivity of the retrieval to the true atmospheric state), error estimations and quality flags. Since 2017, global-scale IASI + GOME2 retrievals have routinely been produced by the French data centre AERIS, and they are publicly available (see https://www.aeris-data.fr and http://cds-espri.ipsl.fr). 

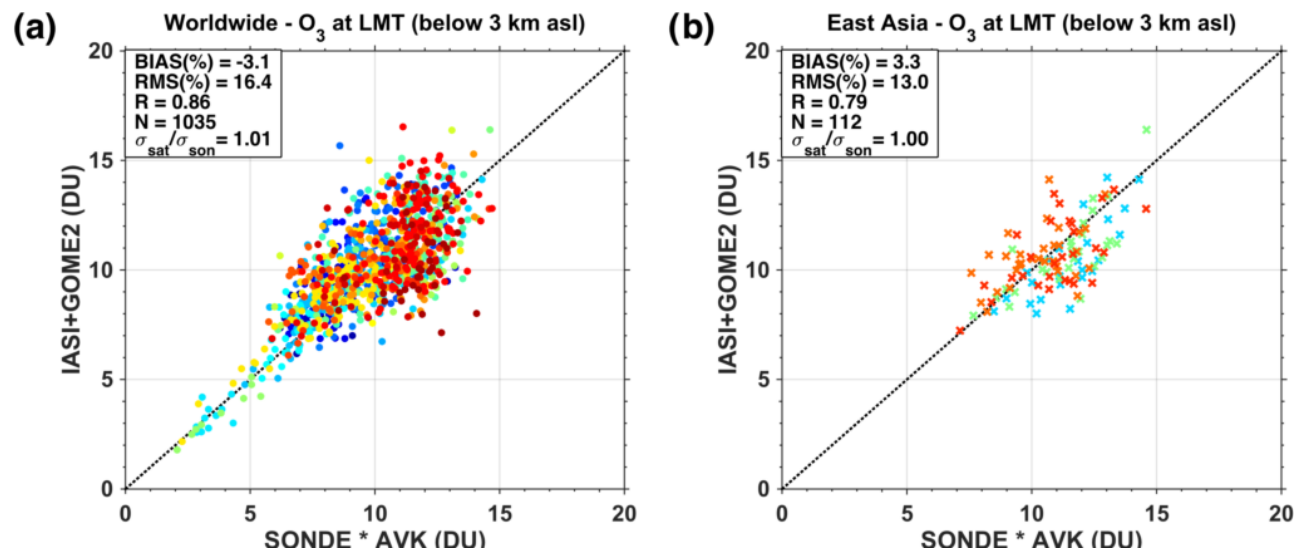

Figure 1. Validation of IASI + GOME2 retrieval of $\mathrm{O}_{3}$ (in Dobson units, DU) in the LMT (between the surface and $3 \mathrm{~km} \mathrm{a.s.1.)} \mathrm{by} \mathrm{comparison}$ with ozonesondes during 2009 and 2010 launched from (a) 46 stations spread worldwide and (b) 3 Japanese stations (Sapporo, Tateno and $\mathrm{Naha}$ ) in the region $25-45^{\circ} \mathrm{N}, 110-150^{\circ} \mathrm{E}$. Averaging kernels of IASI + GOME2 are used for smoothing ozonesonde measurements for accounting for satellite retrieval sensitivity. The symbol $\sigma_{\text {sat }} / \sigma_{\text {sonde }}$ is the ratio between the SDs of the sonde data and the satellite retrievals.

Table 1. Validation of IASI + GOME2 ozone retrievals in the LMT against ozonesondes measurements from 46 stations distributed worldwide (and over East Asia in the region $25-45^{\circ} \mathrm{N}, 110-150^{\circ}$ E, i.e. 3 Japanese stations) launched in 2009 and 2010 , during all seasons. We account for the satellite retrieval sensitivity by smoothing ozonesonde profiles with averaging kernels of IASI + GOME2 pixels with centres collocated within $\pm 1^{\circ}$ of latitude and longitude from the station launching the sonde. Ozonesonde-derived LMT ozone columns are calculated by vertical integration and compared with the average of IASI + GOME2 collocated retrievals. Biases and rms differences are given in Dobson units (DU), and percentage in parentheses. Scatter plots of these datasets are provided in Fig. 1.

\begin{tabular}{lrr}
\hline $\begin{array}{l}\text { IASI + GOME2 retrievals at } \\
\text { the LMT vs. ozonesondes }\end{array}$ & $\begin{array}{r}\text { Ozonesondes distributed } \\
\text { worldwide }\end{array}$ & $\begin{array}{r}\text { Ozonesondes over } \\
\text { East Asia }\end{array}$ \\
\hline Bias & $-0.31(-3.1 \%)$ & $0.37(3.3 \%)$ \\
Correlation & 0.85 & 0.76 \\
rms difference & $1.62(16 \%)$ & $1.43(13 \%)$ \\
SD ratio & 1.01 & 1.00 \\
Number of ozonesondes & 1035 & 112 \\
\hline
\end{tabular}

\subsubsection{Validation of IASI + GOME2 in the LMT against ozonesondes}

An assessment of the quality of IASI + GOME2 for retrieving LMT ozone is presented in Fig. 1 and summarised in Table 1. It is based on a comparison of IASI + GOME2 retrievals and ozonesondes measurements, for the first time spread at the global scale and for all seasons during 2 years. We consider ozonesondes launched from 46 different sites (spread worldwide during the years 2009 and 2010; provided by the World Ozone and Ultraviolet radiation Data Centre WOUDC, http://www.woudc.org). Vertical resolution of the ozonesonde profiles is about $\sim 150 \mathrm{~m}$, and their errors are about $\pm 5 \%$ (Deshler et al., 2008). Coincidence criteria are spatial collocation of $1^{\circ}$ latitude/longitude between the locations of the launching stations of the sondes and the centre points of satellite pixels (as for Keim et al., 2009; Dufour et al., 2012; Cuesta et al., 2013) and a time frame of $12 \mathrm{~h}$ from the MetOp-A morning overpass (at 09:30 local time). These differences in time and location induce part of the random differences between the satellite retrievals and the ozonesondes. The comparison is made for each ozonesonde with the average of collocated satellite retrievals (thus partly reducing random errors). To account for the retrieval sensitivity, we calculate "smoothed" ozonesonde measurements (indicated in Fig. 1 as "SONDE*AVK") by interpolating at the satellite retrieval vertical grid (with $1 \mathrm{~km}$ vertical resolution below $26 \mathrm{~km}$ ), convoluting with each of the averaging kernels (AVKs) of the collocated satellite retrievals and then taking the average. Only quality-assured retrievals of IASI + GOME2 are used (discarding too-high fitting residuals, cloud fraction above $30 \%$, aberrant retrievals of surface temperatures, ozone profiles or AVKs). After cloud screening and quality checks, the number of sondes with coincident IASI + GOME2 data used for this comparison is 1035 .

The comparison at the worldwide scale shows a good agreement of IASI + GOME2 and ozonesondes in the lowermost troposphere, with a weak mean bias $(-3 \%)$, a good correlation (0.85), a very similar variability (a ratio of standard deviations (SDs) of 1.0) and a precision of $16 \%$ (esti- 
Table 2. Comparison of ozone in situ measurements at the surface from 11 EANET stations over the Japanese islands with IASI + GOME2 and IASI-only retrievals in the LMT, for two major ozone outbreaks on 4-9 April and 4-9 May 2009. We consider in situ measurements at 10:00 Japan Local Time (JLT) and the average of collocated satellite retrievals $\pm 1^{\circ}$ of latitude and longitude. We only account for coincidences with both IASI + GOME2 and IASI retrievals. Biases and rms differences are given in ppb mixing ratio and percentage in parentheses. Scatter plots of these datasets are provided in Fig. 2. A selection of the data with limited gradient (lower than 10 ppb $\mathrm{km}^{-1}$ in absolute value) of ozone between the surface and $2 \mathrm{~km}$ (according to CHASER analyses) is considered.

\begin{tabular}{lrrrr}
\hline & \multicolumn{2}{c}{ IASI + GOME2 } & \multicolumn{2}{c}{ IASI } \\
& \multicolumn{2}{c}{ vs. surface measurements } & \multicolumn{2}{c}{ vs. surface measurements } \\
\hline & $\begin{array}{r}\text { Limited gradient } \\
\text { surface-2 km }\end{array}$ & All cases & $\begin{array}{r}\text { Limited gradient } \\
\text { surface-2 km }\end{array}$ & All cases \\
\hline Mean bias & $-3.4(-5.4 \%)$ & $-3.0(-4.8 \%)$ & $-15.6(-24.7 \%)$ & $-15.6(-24.7 \%)$ \\
Correlation $R$ & 0.69 & 0.63 & 0.48 & 0.46 \\
rms & $12.4(19.7 \%)$ & $13.5(21.3 \%)$ & $19.5(31.0 \%)$ & $20.0(31.8 \%)$ \\
difference & & & 0.65 & 0.57 \\
SD ratio & 1.10 & 0.97 & 44 & 52 \\
Number of & 44 & 52 & & \\
measurements & & & & \\
\hline
\end{tabular}

mated as the root-mean-squared difference between the two datasets; see Fig. 1a). These good results are very similar to those obtained in a first validation exercise over Europe during the summer of 2009 , with practically the same correlation, precision, variability and weak bias (Cuesta et al., 2013). As this paper focuses on East Asia (particularly at $25-45^{\circ} \mathrm{N}, 110-150^{\circ} \mathrm{E}$ ), we also present the comparison for all sondes available over this region in 2009-2010 (112 sondes after cloud screening and quality checks), launched from the three Japanese sites of Sapporo, Tateno (Tsukuba, near Tokyo) and Naha (Fig. 1b). In this case, IASI + GOME2 shows similarly good performance, with a weak bias (3\%), the same variability as that of sondes, a precision of $13 \%$ and a good correlation (0.76) slightly lower with respect to the global comparison (probably partly linked to a lower variability in the measurements).

\subsubsection{Capacity of IASI + GOME2 to observe near-surface ozone}

An additional quality assessment is shown in Figs. 2 and 3, which evaluate the capacity of IASI + GOME2 to observe near-surface ozone pollution over East Asia. IASI + GOME2 retrievals in the LMT are compared with in situ measurements at the surface, from nine stations of the EANET (Acid Deposition Monitoring Network in East Asia, http: //www.eanet.asia) network over East Asia, one station from the GAW (Global Atmosphere Watch, http://www.wmo.int) network and one station at Fukue Island $\left(32.8^{\circ} \mathrm{N}, 128.7^{\circ} \mathrm{E}\right.$; e.g. Kanaya et al., 2016) operated by the JAMSTEC Institute (Japan Agency for Marine-Earth Science and Technology; see the location of all these stations in Fig. 3a and b). These stations are representative of background rural environment over several Japanese islands. We consider the two major ozone pollution events observed at the surface over Japan during the springtime 2009, one on 4-9 April and the other on 4-9 May 2009 (as suggested by higher ozone surface concentrations measured by EANET/GAW/JAMSTEC). Collocation in time and space is assumed within $\pm 1 \mathrm{~h}$ and $\pm 1^{\circ}$ latitude/longitude respectively. The comparison is made between the surface in situ hourly measurements for the satellite overpass time and the average of collocated satellite retrievals. Table 2 presents the results of the comparison of all coincident satellite retrievals (both for IASI + GOME2 and IASI only) and surface measurements (the three datasets are available for each coincidence). We consider two sets of surface measurements in order to account for IASI + GOME2 LMT sensitivity (which peaks near $2 \mathrm{kma}$ a.s.l. over land): (i) those corresponding to vertical gradients $\Delta \mathrm{O}_{3}^{\text {surf.-2 } \mathrm{km}}$ between the surface and $2 \mathrm{~km}$ lower than $\pm 10 \mathrm{ppb} \mathrm{km}^{-1}$ and (ii) the whole dataset (respectively 44 and 52 coincidences). The gradient $\Delta \mathrm{O}_{3}^{\text {surf.-2 } \mathrm{km}}$ is estimated from analyses of the tropospheric ozone distribution derived from the CHASER chemistry-transport model (CHemical AGCM for Study of atmospheric Environment and Radiative forcing; see Sect. 2.3). Figures 2 and 3 shows respectively the scatter of points for the case with limited $\Delta \mathrm{O}_{3}^{\text {surf.- } 2 \mathrm{~km}}$ (similar to that for all measurements) and an illustration of the horizontal distribution of ozone satellite retrievals and surface observations. Ozone concentrations in the LMT are provided as volume mixing ratios in ppb (parts per billion), calculated as the ratio of LMT partial columns (in molecules per square centimetre) of ozone and air (in Figs. 2-14 and also used for $\mathrm{CO}$ and other partial columns). 
(a)

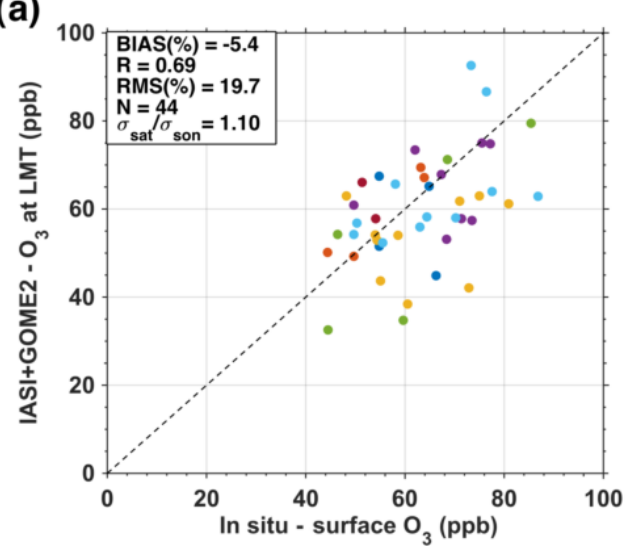

(b)

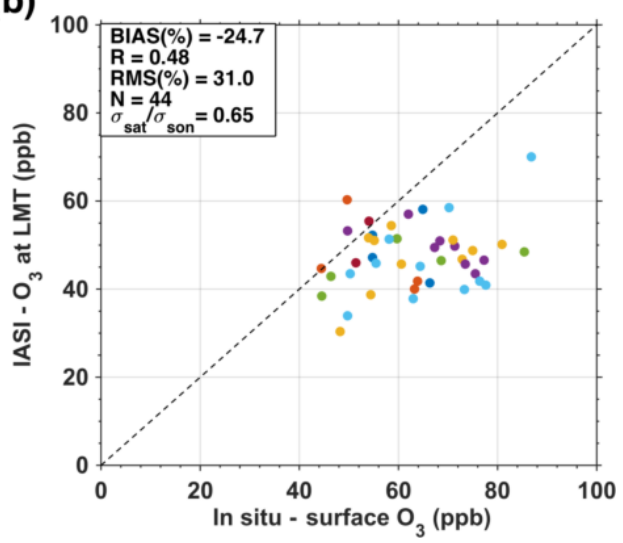

Figure 2. Evaluation of the capacity of IASI + GOME2 to retrieve near-surface ozone: comparisons of (a) IASI + GOME2 and (b) IASIonly retrievals with surface ozone observations from 11 EANET/GAW surface in situ stations over East Asia, during the two greatest East Asian ozone pollution events in springtime 2009 (from 4 to 9 April and from 4 to 9 May 2009). The figures show cases with vertical gradient of ozone concentration between the surface and $2 \mathrm{~km}$ altitude below $10 \mathrm{ppb} \mathrm{km}^{-1}$ (according to CHASER model analysis). This is a direct comparison without smoothing by averaging kernels. Colours indicate different days of the comparison. The symbol $\sigma_{\text {sat }} / \sigma_{\text {sonde }}$ is the ratio between the SDs of the sonde data and the satellite retrievals. Ozone concentrations in the LMT are provided as volume mixing ratios in ppb, calculated as the ratio of LMT partial columns (in $\mathrm{mol} \mathrm{cm}^{-2}$ ) of ozone and air (in Figs. 2-14 and also used for CO and other partial columns).

(a)

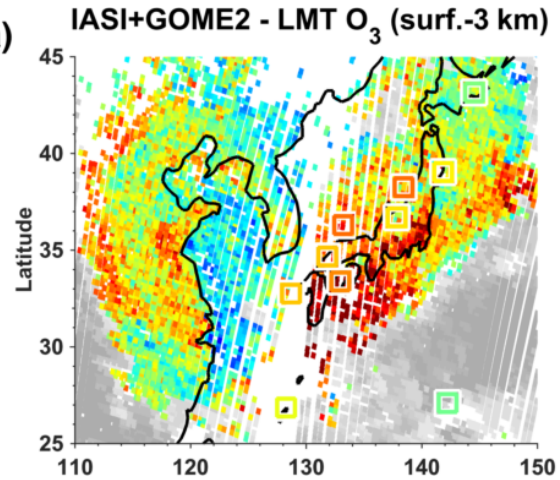

(b)

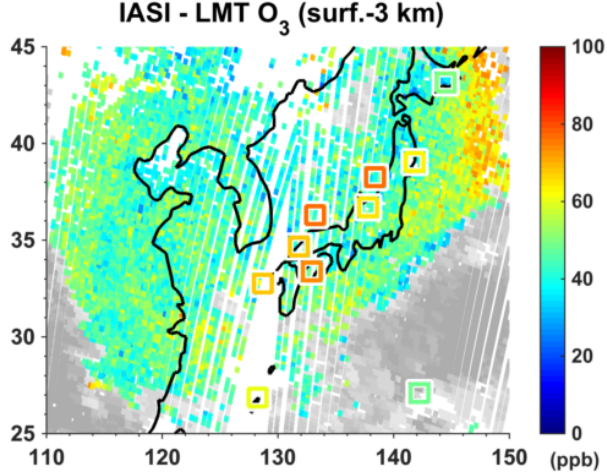

IASI - height of max. sensitivity at LMT (c)

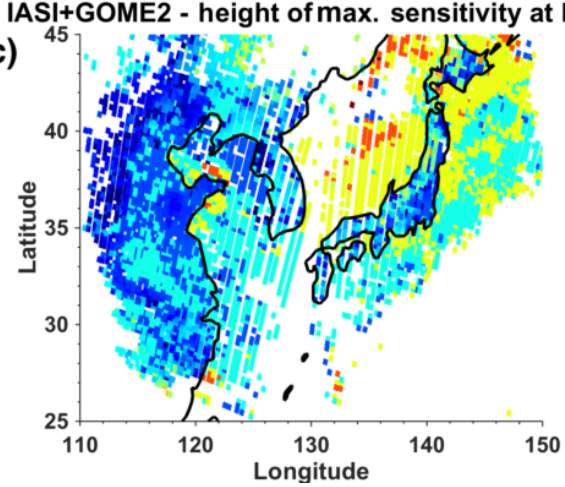

(d)

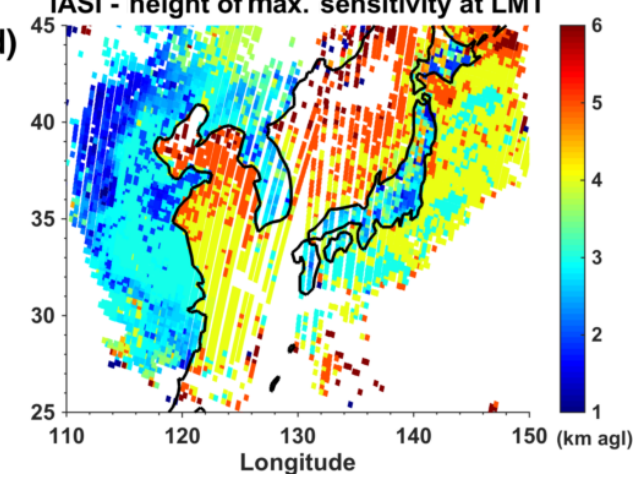

Figure 3. Example of comparison on 9 April 2009 over East Asia of (a) IASI + GOME2 and (b) IASI retrievals of LMT ozone (from the surface up to $3 \mathrm{~km}$ a.s.l. in both cases) with surface observations (squares in panels a and $\mathbf{b}$ ). Grey-shaded pixels show cloud fractions above 0.3 , as derived from the GOME-2 Fresco algorithm. Heights of maximum sensitivity of the LMT ozone partial columns are shown for (c) IASI + GOME2 and (d) IASI. 
Figures 2a and 3a show a good agreement between IASI + GOME2 and the ozone in situ observations at the surface. To the authors' knowledge, this is the first time that such agreement is found for a satellite retrieval of ozone and surface measurements. IASI + GOME2 observations show a fairly good correlation (up to 0.69), a mean bias of $-5 \%$, a precision of $20 \%$ (similar to the retrieval error of IASI + GOME2 in the LMT) and a similar SD with respect to the surface in situ measurements. A slightly lower correlation (0.63) is remarked when comparing all observations (with any values of $\Delta \mathrm{O}_{3}^{\text {surf.- } 2 \mathrm{~km}}$ ) of the period (52 cases), but the agreement remains fairly good. This is illustrated for one of the days in Fig. 3a, where IASI + GOME2 clearly captures the high concentrations of the ozone plumes over the Sea of Japan, south Japan and the Pacific. The multispectral satellite approach is also capable of observing some of the horizontal gradients within the plume, such as the ozone concentrations over the Japanese main island that are lower (60-70 ppb) than those over the ocean ( $>80 \mathrm{ppb})$.

The uniqueness of the performance of IASI + GOME2 to retrieve near-surface ozone is shown by comparing the same in situ measurements with other satellite retrievals, such as a single-band IASI retrieval (described in Sect. 2.2). We use the LISA IASI product, which offers the highest sensitivity to ozone below $6 \mathrm{~km}$ (LT) among three French IASI products (Dufour et al., 2012) and is also largely higher than a GOME-2-only product (shown by Cuesta et al., 2013). This IASI retrieval is often used to analyse ozone enhancements in the lower troposphere over Europe (e.g. Eremenko et al., 2008) and East Asia (e.g. Dufour et al., 2015), as also done with retrievals from OMI measurements also over East Asia (Hayashida et al., 2015). The IASI LMT retrieval sensitivity peaks approximately around $3 \mathrm{~km}$ a.s.l. over land and 4-5 km over ocean, thus being $1 \mathrm{~km}$ higher than that for IASI + GOME2 both over land and ocean (see Fig. 3c and d). Figure $2 b$ shows that the IASI-only retrieval is unable to clearly capture the high ozone concentrations observed at the surface, particularly those above $60 \mathrm{ppb}$. The scatter of points for IASI retrievals is rather flat, highlighting a lack of sensitivity to LMT ozone also shown on the horizontal map of Fig. 3b. The single-band retrieval variability is much lower than that measured at the surface (the ratio of SDs is 0.65 at most). Mean root mean square ( $\mathrm{rms}$ ) differences are above $30 \mathrm{ppb}$, and the correlation coefficient below 0.5 . On the other hand, only IASI + GOME2 captures surface ozone variations over the whole range from 40 to $90 \mathrm{ppb}$ (Fig. 2a) and shows a unique performance to capture surface ozone variability.

\subsection{Other satellite observations}

In order to analyse the origin and evolution of ozone pollution plumes, the following correlative datasets are used: $\mathrm{CO}$ and $\mathrm{O}_{3}$ retrievals from IASI, and $\mathrm{NO}_{2}$ and $\mathrm{CH}_{2} \mathrm{O}$ observations derived from GOME-2 and OMI. Morning time (around
09:30 local time) datasets from IASI and GOME-2 are derived from the same spectra as those used in synergism by IASI + GOME2. OMI overpass occurs in the early afternoon (near 13:30 local time).

The CO retrievals used in the present paper are derived from IASI radiances using the FORLI algorithm (Fast Optimal Retrievals on Layers for IASI; Hurtmans et al., 2012), from the Université Libre de Bruxelles (ULB) and the Laboratoire Atmosphères, Milieux, Observations Spatiales (LATMOS). This approach uses pre-calculated lookup tables of absorbance cross sections at various pressures and temperatures, and an optimal estimation method for the inverse scheme. The algorithm derives vertical profiles of $\mathrm{CO}$, on a grid of 18 equidistant layers of $1 \mathrm{~km}$ of depth from the surface up to $18 \mathrm{~km}$, and a unique layer from 18 to $60 \mathrm{~km}$. Radiative transfer calculations use operational MetOp-A L2 temperature and humidity profiles, and surface emissivity climatologies (Zhou et al., 2011). A priori $\mathrm{CO}$ profiles are taken from MOZAIC (Measurements of OZone aboard in-service AIrbus airCraft), ACE-FTS, for higher altitudes (Clerbaux et al., 2005) and the LMDz-INCA global chemistry-transport model (Haugustaine et al., 2004). FORLI provides vertical profiles, total and partial columns of $\mathrm{CO}$ derived by profile integrations, averaging kernels, error estimations and quality flags (supplied by AERIS and LATMOS). Comparisons of $\mathrm{CO}$ total columns derived from FORLI-IASI showed an agreement better than $7 \%$ and no significant bias with respect to other satellite products (for the Northern Hemisphere; George et al., 2009) and groundbased retrievals from six NDACC stations (Kerzenmacher et al., 2012). A validation of lower (surface-480 hPa) and upper (480-225 hPa) tropospheric columns with respect to MOZAIC measurements found an agreement of respectively 21 and $10 \%$, and correlations of respectively $\sim 0.8$ and $\sim 0.7$ (De Wachter et al., 2012).

In the present study, we use $\mathrm{CO}$ retrievals in the LT integrated from the surface up to $6 \mathrm{kma.s.1}$. (equivalent to surface- $480 \mathrm{hPa}$ ), validated by De Wachter et al. (2012) and presenting heights of maximum of sensitivity located at 3$5 \mathrm{~km}$ altitude (i.e. at the middle of this partial column; see Sect. 4). LT partial columns are retrieved with 0.83 degree of freedom (DOF, i.e. number of independent pieces of information in the retrieved profile) on average over the region and period studied in the paper. This product provides significant information on $\mathrm{CO}$ variability below $3 \mathrm{kma.s.1.,} \mathrm{as}$ DOF in the LMT are 0.51 on average.

For estimating the ratio of enhancements of $\mathrm{O}_{3}$ and $\mathrm{CO}$ in the LMT (hereafter referred to as $\Delta \mathrm{O}_{3} / \Delta \mathrm{CO}$ ) during individual long-range transport events, we use $\mathrm{O}_{3}$ and $\mathrm{CO}$ satellite observations (mixing ratios in ppb) after subtracting background levels, as done for analysing airborne in situ data during the PHOBEA I and II experiments over the northeast Pacific (Price et al., 2004). We empirically estimate these background concentrations as the daily average concentration minus the SD over the region of analysis $\left(20-48^{\circ} \mathrm{N}\right.$, 
$\left.110-150^{\circ} \mathrm{E}\right)$. For the event in early May 2009 , we derive background levels around $\sim 46 \mathrm{ppb}$ and $\sim 126 \mathrm{ppb}$ for the observations of respectively LMT $\mathrm{O}_{3}$ and LT CO. We use the same criteria for deriving $\Delta \mathrm{O}_{3} / \Delta \mathrm{CO}$ in the LMT from models (Weather Research and Forecasting with Chemistry (WRF-Chem) and CHASER; see Sects. 2.3 and 4).

We also use single-band IASI-only retrievals of ozone (Eremenko et al., 2008; LISA product in Dufour et al., 2012) in order to analyse the distribution of ozone between 3 and $6 \mathrm{~km}$ a.s.l. This single-band IASI product is similar to IASI + GOME2 but only use infrared measurements (both approaches using a Tikhonov-Philips regularisation and the KOPRA radiative transfer code in similar configuration). By comparing IASI-only and IASI + GOME2 ozone retrievals, one may identify ozone plumes located below $3 \mathrm{~km}$ a.s.l. and those located between 3 and $6 \mathrm{~km}$ a.s.l. (as remarked by Cuesta et al., 2013). Indeed, we expect that high ozone concentrations clearly depicted by IASI + GOME 2 and not by IASI are located in the LMT below $3 \mathrm{~km}$ a.s.l. Ozone plumes located at 3-6 kma.s.1. are shown by both IASI + GOME2 and IASI. Note that, since the DOF for IASI + GOME2 is lower than 1 in the LMT, multispectral outputs depend as well on ozone concentrations up to 5 or $6 \mathrm{~km}$ a.s.l., and they alone do no reveal whether the ozone plumes are located in the LMT or at 3-6 kma.s.1.

Satellite retrievals of $\mathrm{NO}_{2}$ and $\mathrm{CH}_{2} \mathrm{O}$ from GOME-2 (overpass around 09:30 local time) and OMI (13:30 local time) are used to indicate the availability of ozone precursors. These datasets are provided by TEMIS (Tropospheric Emission Monitoring Internet Service, http://www.temis.nl) and BIRA-IASB (Belgian Institute for Space Aeronomy-Institut royal d'Aéronomie Spatiale de Belgique) for $\mathrm{CH}_{2} \mathrm{O}$ (http: //h2co.aeronomie.be). Retrievals of $\mathrm{NO}_{2}$ from GOME-2 and OMI are derived respectively by the algorithms TM4NO2A version 2.3 (Boersma et al., 2004) and DOMINO version 2.0 (Boersma et al., 2011). These approaches follow three steps: using differential optical absorption spectroscopy (DOAS) to obtain $\mathrm{NO}_{2}$ slant columns from reflectance spectra, separating the stratospheric and tropospheric contribution to the slant column, and converting the tropospheric slant column to a vertical column with the tropospheric air mass factor. Uncertainties for tropospheric $\mathrm{NO}_{2}$ retrievals are estimated as $35-60 \%$ for GOME-2 and $25 \%$ for OMI. Total columns of $\mathrm{CH}_{2} \mathrm{O}$ are retrieved with the BIRA-IASB algorithm version 14 (De Smedt et al., 2008), also based on DOAS technique and air mass factor estimations. Uncertainties of single $\mathrm{CH}_{2} \mathrm{O}$ slant column observations typically range from about 10 to $200 \%$ when exceeding the global background $\left(\sim 4 \times 10^{15} \mathrm{~mol} \mathrm{~cm}^{-2}\right)$. For reducing random errors, datasets are averaged in regular grids of $1^{\circ} \times 1^{\circ}$ and $2^{\circ} \times 2^{\circ}$ respectively for $\mathrm{NO}_{2}$ and $\mathrm{CH}_{2} \mathrm{O}$.

\subsection{Chemistry-transport models: WRF-Chem \& CHASER}

In the present study, we use WRF-Chem and CHASER chemistry-transport models for completing the description of the ozone pollution outbreak across East Asia in early May 2009 and for verifying consistency with satellite observations. While WRF-Chem is a regional model (Grell et al., 2005) operating in forecast mode over Asia (Takigawa et al., 2007), CHASER is a global model (Sudo et al., 2002; Sudo and Akimoto, 2007; Sekiya and Sudo, 2014) with coarser spatial resolution but with enhanced accuracy through assimilation of several satellite retrievals of atmospheric pollutants (Miyazaki et al., 2012, 2015) and with higher model top height. These models provide useful insights on the detailed vertical distribution (e.g. surface concentrations) and diurnal evolution of tropospheric $\mathrm{O}_{3}$ and $\mathrm{CO}$ over East Asia, in complement to daily satellite observations. The daily evolution of ozone enhancement in the LMT is compared between the models and the satellite data. For this, we estimate background levels of $\mathrm{O}_{3}$ and $\mathrm{CO}$ for each dataset using the same criteria (i.e. daily average minus SD over the domain; see Sect. 2.2). We derive concentrations of $\mathrm{O}_{3}$ and $\mathrm{CO}$ in the LMT by vertical integration from the surface up to $3 \mathrm{~km}$ a.s.l. (without any smoothing by the satellite AVKs). Moreover, we perform sensitivity studies with CHASER (in forecast mode), accounting or not for the stratospheric contribution of ozone in order to identify the tropospheric or stratospheric origin of this pollutant. In the figures of the paper, we show one of the models or both of them according to the following criteria: (i) WRF-Chem describes the structure of plumes of $\mathrm{LMT} \mathrm{O}_{3}$ and $\mathrm{CO}$ with finer spatial resolution (Sect. 3); (ii) CHASER forecasts with and without stratospheric ozone distinguish tropospheric ozone formed in the troposphere from that originating from the stratosphere (Sects. 3 and 4); (iii) both WRF-Chem and CHASER are used for showing the temporal Lagrangian evolution of $\mathrm{O}_{3}, \mathrm{CO}$ and $\mathrm{NO}_{2}$ for polluted air masses (Sect. 4); and (iv) CHASER analyses indicate the vertical gradients of ozone between the surface and $2 \mathrm{~km}$ altitude with presumably good absolute accuracy provided by assimilation of various observations (Sect. 2).

For the current application, WRF-Chem resolution is set to 37 vertical layers from the surface up to $100 \mathrm{hPa}(\sim 15 \mathrm{~km}$ altitude) and a Lambert conformal conic projection of horizontal pixels of about $\sim 0.9^{\circ} \times 0.9^{\circ}$. Emissions from automobiles and other anthropogenic sources are taken from EAgrid 2000 (East Asian Air Pollutant Emissions Grid Inventory; K. Murano, personal communication) and the JCAP (Japan Clean Air Program; Kannari et al., 2007) over Japan for automobiles. Surface emissions over China and North and South Korea are taken from REAS (Regional Emission Inventory in Asia; Ohara et al., 2007) version 1.11, and over Russia from EDGAR (Emission Database for Global Atmospheric Research; Olivier et al., 1996) version 3.2. Biogenic emis- 
sions are based on Guenther et al. (1993). The lateral boundaries of chemical species are taken from the global CHASER model every $3 \mathrm{~h}$. The system is driven by meteorological data from the Mesoscale Model (MSM) of the Japan Meteorological Agency (JMA).

CHASER analyses are obtained from an advanced chemical data assimilation system combining satellite observations of several chemical compounds: $\mathrm{NO}_{2}, \mathrm{O}_{3}, \mathrm{CO}$ and $\mathrm{HNO}_{3}$ measurements from OMI, TES, MOPITT and the Microwave Limb Sounder (MLS). Assimilation is performed according to the local ensemble transform Kalman filter technique (Hunt et al., 2007), which simultaneously optimises targeted chemical species, as well as the emissions of $\mathrm{O}_{3}$ precursors (i.e. $\mathrm{NO}_{x}$ and $\mathrm{CO}$ ), while taking their chemical feedbacks into account. Comparisons against independent data show that data assimilation results in substantial improvements. It reduces biases for tropospheric $\mathrm{NO}_{2}$ columns by $40-85 \%$, for lower-tropospheric $\mathrm{CO}$ concentrations in the Northern Hemisphere by $40-90 \%$ and for $\mathrm{O}_{3}$ in the middle and upper troposphere by $30-40 \%$. Data assimilation also mostly removed the model's negative bias in surface $\mathrm{CO}$ concentrations in the Northern Hemisphere. The error reduction for $\mathrm{O}_{3}$ was generally smaller in the lower troposphere than in the middle and upper troposphere because of the reduced sensitivity of the assimilated TES retrievals to lower-tropospheric ozone. The CHASER forecast model includes detailed chemical and transport processes in the troposphere, including 88 chemical and 25 photolytic reactions with 47 chemical species, and has a horizontal resolution of T42 $\left(2.8^{\circ}\right)$ and 32 vertical levels from the surface to $4 \mathrm{hPa}$ for the present study. Sekiya et al. (2018) have recently developed a highresolution version of CHASER with $0.56^{\circ}$ horizontal resolution and demonstrated improved performances over areas with strong local sources with respect to the $2.8^{\circ}$ resolution version. Nevertheless, the CHASER model with $2.8^{\circ}$ resolution is capable of properly simulating synoptic ozone patterns.

CHASER is coupled to the Center for Climate System Research/National Institute for Environmental Studies (CCSR/NIES) Atmospheric General Circulation Model (AGCM) version 5.7b. The AGCM fields are nudged toward the National Centers for Environmental PredictionDepartment of Energy (NCEP-DOE) Atmospheric Model Intercomparison Project II (AMIP-II) reanalysis (Kanamitsu et al., 2002) at every time step of the AGCM to reproduce past meteorological fields. Anthropogenic, biomass burning and biogenic/soil emissions are respectively based on EDGAR version 3.2 (Olivier et al., 2005), the Global Fire Emissions Data base (GFED) version 2.1 (Randerson et al., 2007) and the Global Emissions Inventory Activity (GEIA) inventory (Guenther et al., 1995). Surface emissions over Asia were obtained from REAS.

For the sensitivity analysis, CHASER simulations of ozone "from the troposphere" (not accounting for stratospheric ozone) are obtained by setting to zero ozone concen- trations above $100 \mathrm{hPa}$, starting from 1 January 2009. Differences between ozone concentrations from full simulations and those not accounting for the stratospheric contribution provide an estimation of the distribution of ozone transported from the stratosphere. For consistency, no data assimilation is performed in either of the two simulations of this sensitivity analysis.

\subsection{Meteorological data: ERA-Interim reanalyses and HYSPLIT dispersion model}

Meteorological conditions leading to production of ozone pollution and transport across East Asia are described in Sect. 3 with ERA-Interim reanalyses (Dee et al., 2011) produced by ECMWF (European Centre for MediumRange Weather Forecasts). We use meteorological fields (downloaded from http://climserv.ipsl.polytechnique.fr) with global coverage, a horizontal resolution of $0.75^{\circ} \times 0.75^{\circ}, 37$ pressure levels and a time step of $6 \mathrm{~h}$ (interpolated for other hours). Wind, geopotential height and equivalent potential temperature fields describe atmospheric circulation and the locations of synoptic high- and low-pressure systems. Additionally, forecasted atmospheric boundary mixing layer top heights from ERA-I are used in the analysis of the vertical distribution of LMT ozone derived from IASI + GOME2.

Pathways of polluted air masses transported across East Asia are estimated using the Hybrid Single Particle Lagrangian Integrated Trajectory Model (HYSPLIT) dispersion model (Stein et al., 2015; Rolph et al., 2017; https: //ready.arl.noaa.gov). This tool can simultaneously track a total of 12500 air parcels released at a location and altitude and transported during $24 \mathrm{~h}$ according to meteorological fields. For the present analysis, we set the starting altitudes from the surface up to $3 \mathrm{~km}$ (i.e. in the LMT, which is the layer observed by IASI + GOME2) and use built-in model reanalysis from NCEP/NCAR (National Center for Atmospheric Research) with a horizontal resolution of $2.5^{\circ} \times 2.5^{\circ}$ and 18 (29) pressure (sigma) levels. We run the dispersion model at 00:00 UTC (09:00 Japan Local Time (JLT), close to the MetOp satellite overpass) in forward mode for each day of the ozone pollution event, at the mean arrival location of the air parcels travelling on the previous day. The starting point for the pollution event was determined as the southern portion of the North China Plain (NCP), as suggested by model simulations and high concentration of ozone precursors (see Sect. 3.1). For the first day, we determined the region covered by the pollution plume using the dispersion model in backward mode, starting at the mean location of the air parcels on the second day. 


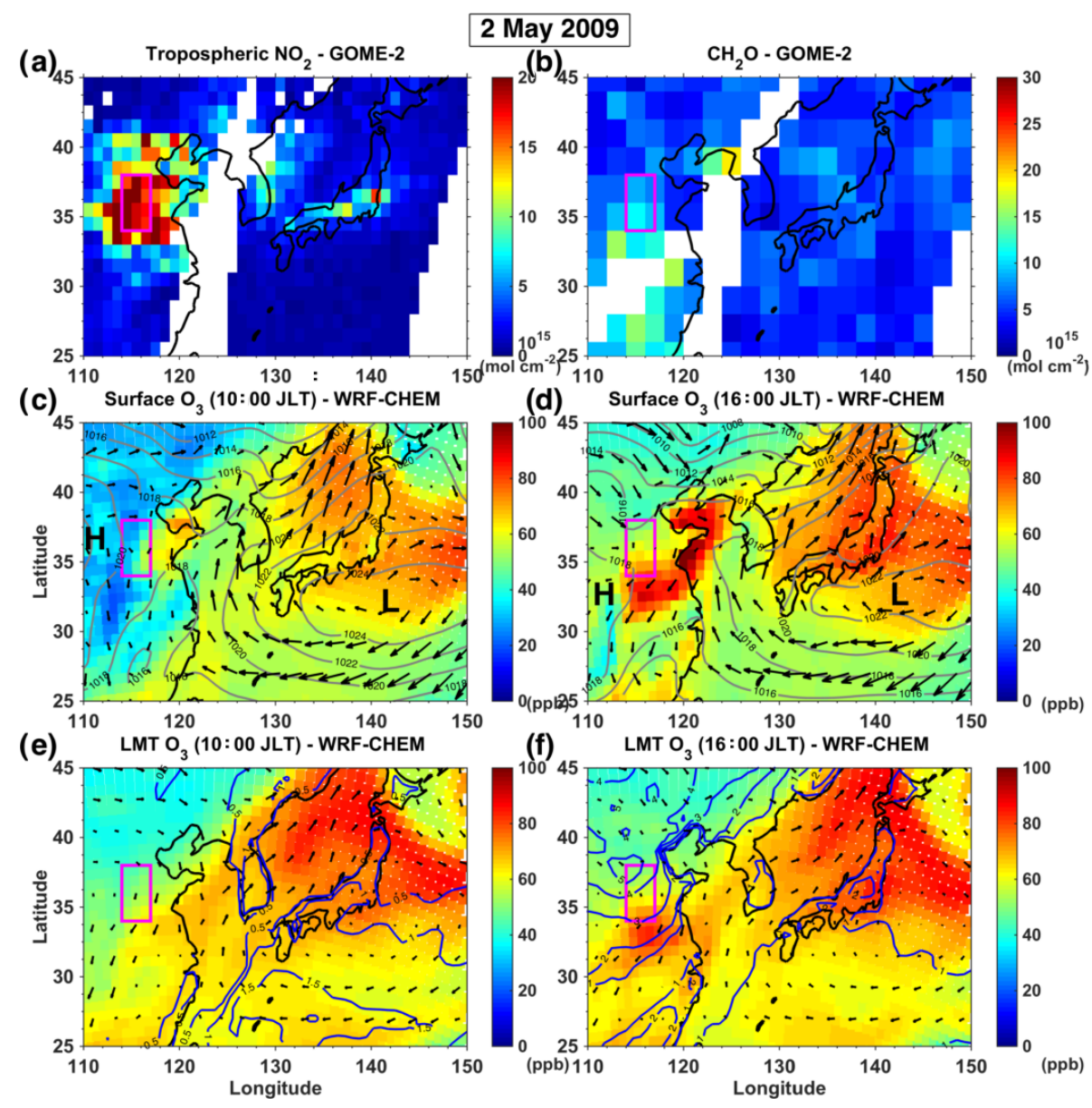

Figure 4. (a) Tropospheric nitrogen dioxide $\left(\mathrm{NO}_{2}\right)$ and (b) formaldehyde $\left(\mathrm{CH}_{2} \mathrm{O}\right)$ distribution over East Asia on 2 May 2009 derived from GOME-2 observations at 09:30 JLT. (c-f) Ozone distribution simulated by the WRF-Chem model at the surface (panels $\mathbf{c}$ and d) and averaged below $3 \mathrm{~km}$ a.g.l. (LMT, panels e and f) in the morning (at 10:00 JLT, panels $\mathbf{c}$ and $\mathbf{e}$ ) and in the afternoon (at 16:00 JLT, panels $\mathbf{d}$ and $\mathbf{f}$ ). Iso-contours in grey (panels $\mathbf{c}$ and $\mathbf{d}$ ) and dark blue (e and $\mathbf{f}$ ) are mean sea level pressure (in hPa) and mixing boundary layer height (in $\mathrm{km}$ a.s.1.) from ERA-I reanalysis. Arrows depict winds at the surface (c, d) and $850 \mathrm{hPa}$ (e, f) from ERA-I. Low and high-pressure systems are indicated by respectively "L" and "H" (in panels c and d). Magenta rectangles in panels indicate the overall location on 2 May 2009 of the tracked air masses during the ozone pollution outbreak of early May 2009.

\section{Ozone pollution outbreak across East Asia in early May 2009}

In this section, we describe the daily evolution of a major ozone pollution outbreak initiated over China and transported across East Asia during the period 2-9 May 2009. First, we focus on the formation of a large ozone plume over the NCP (Sect. 3.1). Next, we analyse the transport of these polluted air masses over the NCP in the northeastern direction (Sect. 3.2) and their subsequent advection by an anticyclonic circulation over northern China and the Korean Peninsula (Sect. 3.3). Finally, these ozone plumes split into two filaments and reach Japan and the Pacific far from the main sources of ozone precursors (Sect. 3.4). According to EANET/GAW/JAMSTEC surface observations over
Japanese islands, this is one of the two largest ozone pollution outbreaks reaching Japan during the springtime of 2009.

\subsection{Ozone plume formation over the NCP on 2 May}

The NCP is a well-known hotspot of pollutant emissions of worldwide relevance (e.g. Richter et al., 2005). On 2 May 2009, large concentrations of ozone precursors, such as nitrogen dioxide $\left(\mathrm{NO}_{2}\right)$ and formaldehyde $\left(\mathrm{CH}_{2} \mathrm{O}\right)$, are observed over the NCP. This is suggested by GOME- 2 satellite retrievals at $34-37^{\circ} \mathrm{N}, 113-117^{\circ} \mathrm{E}$, marked as a magenta rectangle in Fig. $4 \mathrm{a}$ and $\mathrm{b}$. Whereas a dense $\mathrm{NO}_{2}$ plume is mainly formed over the NCP, the highest concentrations of $\mathrm{CH}_{2} \mathrm{O}$ are mainly located south of it (at $25-36^{\circ} \mathrm{N}, 112$ $120^{\circ} \mathrm{E}$ ), reaching the southern part of the NCP. The $\mathrm{NO}_{2}$ and $\mathrm{CH}_{2} \mathrm{O}$ concentrations observed on 2 May 2009 are approximately a factor of 2 higher than the regional monthly av- 

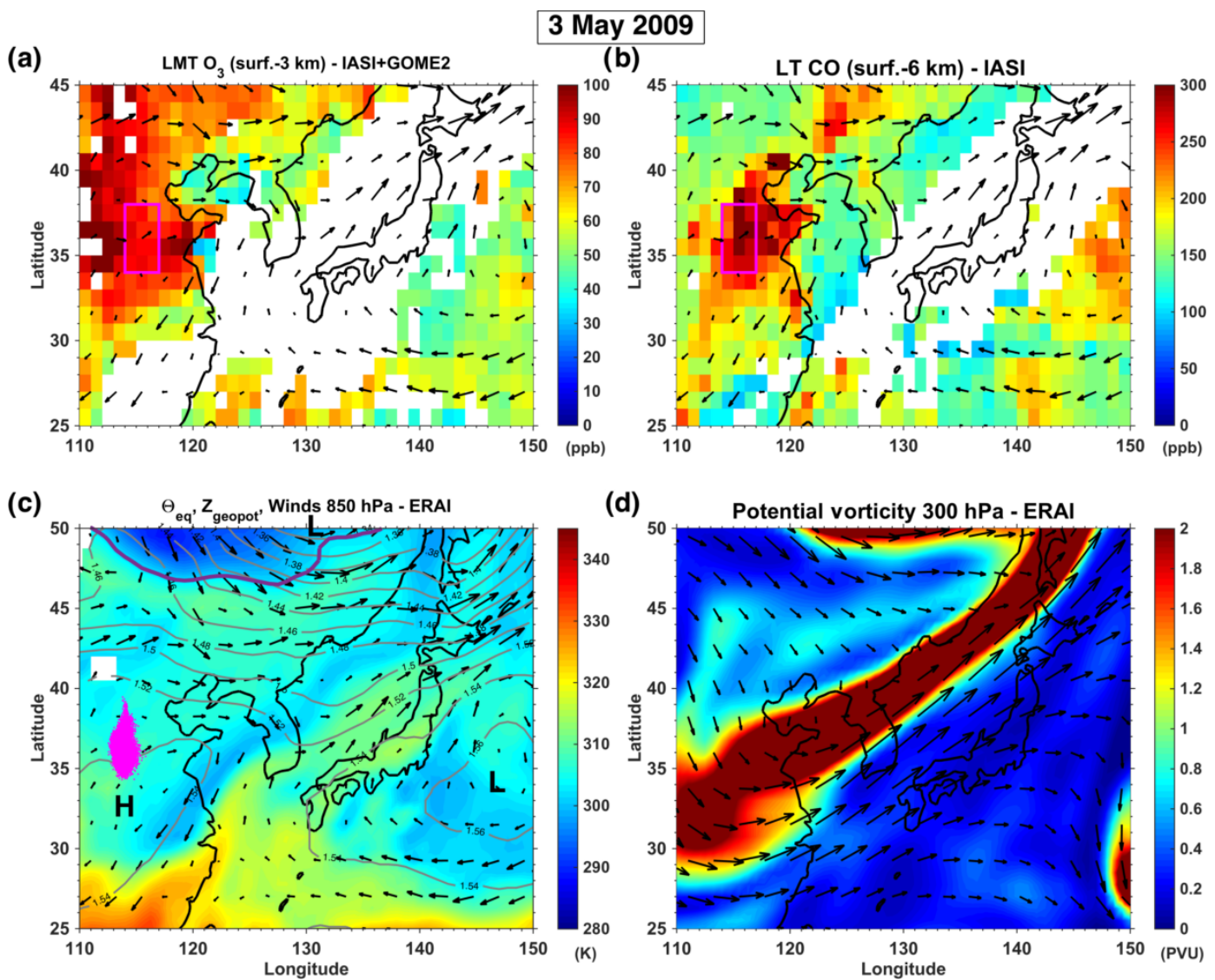

Figure 5. Distribution of gaseous pollutants and the meteorological situation over East Asia on 3 May 2009: (a) lowermost tropospheric ozone derived below $3 \mathrm{~km}$ a.s.l. from IASI + GOME2; (b) carbon monoxide in the lower troposphere (below $6 \mathrm{~km}$ altitude) retrieved from IASI measurements; (c) equivalent potential temperature $\theta_{\text {eq }}$ (colour shading in $\mathrm{K}$ ), geopotential height $Z_{\text {geopot }}($ grey isolines every $20 \mathrm{~m}$ ) and winds at $850 \mathrm{hPa}$ from ERA-I reanalyses; (d) Potential vorticity (colour shading in potential vorticity units, PVU) and winds at $300 \mathrm{hPa}$ from ERA-I. The magenta rectangle in panels (a) and (b) indicates the overall location on 3 May 2009 of the tracked air masses during the ozone pollution outbreak of early May 2009, and the magenta dots in (c) correspond to the precise air parcels locations provided by HYSPLIT. The location of a cold front is shown by a violet curve in panel (c).

erage (also estimated with GOME-2). According to MODIS active fire data over this region, wildfires are negligible in early May 2009 (only very few fire spots are detected; see http://firms.modaps.eosdis.nasa.gov). The short lifetimes of these reactive gases (up to a few hours) prevent the influence of long-range transport. The observed $\mathrm{NO}_{2}$ and $\mathrm{CH}_{2} \mathrm{O}$ plumes are thus likely associated with local anthropogenic emissions from this densely populated and industrialised region. In the following (Sects. 3 and 4), we particularly focus our analysis on the daily evolution of pollutant concentrations originated from these air masses as they are transported across East Asia. In Figs. 4-12, satellite pixels used to describe the evolution of these polluted air masses are depicted by magenta and red rectangles. These boxes contain valid satellite pixels collocated with at least $5 \%$ of the polluted air parcels trajectories simulated by HYSPLIT.

According to model simulations, ozone concentrations over the NCP are relatively low (below $50 \mathrm{ppb}$ ) during the morning of 2 May, both at the surface and within the LMT (up to $3 \mathrm{~km}$ a.s.l., shown in Fig. $4 \mathrm{c}$ and e for WRF-Chem). Therefore, we do not observe any significant residual ozone plume from the previous day within the LMT. As expected for this time of the day (10:00 JLT), the mixing boundary layer over land is rather shallow (with its top below $1 \mathrm{kma.s.l}$; see blue isolines representing the depth of the mixing boundary layer in Fig. 4e). Weather conditions over the region are characterised by very low wind speeds at the lower atmospheric levels associated with marked anticyclonic conditions (see high pressures approaching the NCP from the west at $25-35^{\circ} \mathrm{E}, 110-115^{\circ} \mathrm{E}$ in Fig. $4 \mathrm{c}$ and d). Due to partial cloud cover, IASI + GOME2 retrievals are not available over this region during this day.

Following up with the typical diurnal cycle, ozone is photochemically produced during the afternoon, until reaching concentrations of $\sim 90 \mathrm{ppb}$ near the surface in the southern part of the NCP at 16:00 JLT (according to the WRF-Chem 
model around $34^{\circ} \mathrm{N}, 115^{\circ} \mathrm{E}$; see Fig. $\left.4 \mathrm{~d}\right)$. In the afternoon, the mixing boundary layer over this region is deeply developed with its top near $\sim 2$ kma.g.1. (3.5 kma.s.l., Fig. $4 \mathrm{f}$ ), thus suggesting that the ozone plume freshly formed during the afternoon of this day is well mixed within the LMT.

\subsection{Ozone plume transported over the NCP on 3-4 May}

In the morning of 3 May, anticyclonic conditions prevail over the NCP with a pressure maximum over central China, at the southern outskirts of the NCP (see Fig. 5c). According to the HYSPLIT dispersion model, the ozone plume formed the previous afternoon over southern NCP is transported by weak southerly winds until $35^{\circ} \mathrm{N}, 115^{\circ} \mathrm{E}$ (magenta rectangle in Fig. 5a and b). At this location, high concentrations of both LMT ozone ( $\sim 90 \mathrm{ppb})$ and LT carbon monoxide $(\sim 290 \mathrm{ppb})$ are observed from space respectively by IASI + GOME2 (Fig. 5a) and IASI (Fig. 5b). Collocation of both pollutant plumes over the NCP suggests that these high ozone concentrations are associated with surface anthropogenic emissions, as CO is a tracer for combustionrelated emissions.

Meanwhile, another ozone plume is observed over northeastern China (north of $42^{\circ} \mathrm{N}$ and at $115-135^{\circ} \mathrm{E}$ in Fig. 5a). The origin of this plume is likely associated with a lowpressure system (see "L" and concentric isobars north of $44^{\circ} \mathrm{N}$ and at $120-135^{\circ} \mathrm{E}$ in Fig. 5c). Such systems may both entrain ozone from the stratosphere and the UTLS region down to the lower troposphere and also mix pollution-related ozone within the low atmospheric levels, as analysed for other events in the same region by Dufour et al. (2015). Both phenomena may occur in this case. On the one hand, downward transport of ozone from the stratosphere (likely west of $120^{\circ} \mathrm{E}$ and north of $42^{\circ} \mathrm{N}$ ) is suggested by enhanced potential vorticity at $300 \mathrm{hPa}$ (a tracer of stratospheric air masses) north of $48^{\circ} \mathrm{N}, 130^{\circ} \mathrm{E}$ (Fig. 5d). On the other hand, an anthropogenic contribution of LMT ozone is indicated by the presence of a CO plume observed by IASI east of $122^{\circ} \mathrm{E}$ (and north of $40^{\circ} \mathrm{N}$, Fig. 5b), likely originating from northeastern Chinese emissions. This pollution plume is observed ahead of a cold front (violet curve in Fig. 5c), associated with the low-pressure system north of $44^{\circ} \mathrm{N}$. In this region, we expect the formation of a warm conveyor belt. This ascending air stream typically mixes up the air masses near the surface within the low atmospheric levels (e.g. Cooper et al., 2002; Ding et al., 2009; Foret et al., 2014). Such vertical mixing likely contributes to the observation of nearsurface pollutants by satellite retrieval sensitive within the LMT. At this location $\left(40-45^{\circ} \mathrm{N}, 122-128^{\circ} \mathrm{E}\right)$, models show ozone concentrations only enhanced up to $\sim 50 \mathrm{ppb}$ (Fig. $6 \mathrm{~b}$ for WRF-Chem), near background levels. CHASER clearly simulates the contribution of stratospheric ozone down to the LMT (north of $42^{\circ} \mathrm{N}$ ), but shifted to the west $\left(95-105^{\circ} \mathrm{E}\right.$, not shown). As the paper does not focus on these air masses, a detailed analysis of these differences is beyond the scope of the current paper.

Over the NCP (and also south of it), models simulate relatively high ozone concentrations $(\sim 70 \mathrm{ppb})$ within the LMT at 10:00 JLT (see WRF-Chem in Fig. 6b). As previously mentioned, IASI + GOME2 also retrieves high LMT ozone concentrations over the $\mathrm{NCP}$ (around $35^{\circ} \mathrm{N}, 115^{\circ}$ E, Fig. 5a), but also north of it (differing from simulations in the LMT). At the surface, ozone concentrations simulated by WRFChem remain rather low (near $40 \mathrm{ppb}$ ) at this time of the day (Fig. 6a), probably due to titration during the previous night. This suggests that the high ozone concentrations observed by IASI + GOME2 in the LMT (over the NCP) likely correspond to a plume located within the residual boundary layer and formed during the previous day. Such an ozone plume is simulated by WRF-Chem between 1 and $3 \mathrm{~km}$ altitude at $35-38^{\circ} \mathrm{N}$, while reaching the surface south of $35^{\circ} \mathrm{N}$ (Fig. 6c for WRF-Chem). Both WRF-Chem and collocation with a plume of $\mathrm{CO}$ confirm the anthropogenic origin of the ozone plume in the LMT observed by IASI + GOME2 over the NCP. At this continental location, high $\mathrm{NO}_{2}$ concentrations are also both observed by GOME-2 (Fig. 6d) and simulated by the models (not shown).

The origin of this ozone plume may also be estimated from a comparison between CHASER simulations in two configurations: accounting or not accounting for the contribution of ozone from the stratosphere (see more details in Sect. 2.3). This analysis suggests that the stratospheric contribution over the NCP is practically negligible $(\sim 5 \mathrm{ppb})$ in the LMT (Fig. 6e). Only above the LMT (between 3 and $6 \mathrm{~km}$ a.s.l.) is a higher contribution of ozone $(\sim 30 \mathrm{ppb})$ from a stratospheric filament depicted by CHASER along a front extending from $32^{\circ} \mathrm{N}, 110^{\circ} \mathrm{E}$ to $48^{\circ} \mathrm{N}, 142^{\circ} \mathrm{E}$ (Fig. 6f). This is also suggested by collocated high values of potential vorticity (PV) at $300 \mathrm{hPa}$ from ERA-I (Fig. 5d). IASI-only retrievals also depict this ozone filament above $3 \mathrm{~km}$ a.s.l. (although most pixels are cloudy; not shown).

During the following day (4 May), the anticyclone slowly moves northeastwards and approaches the Yellow Sea, with its pressure maximum at sea level near the coast $\left(36^{\circ} \mathrm{N}\right.$, $122^{\circ}$ E, Fig. 7c). According to HYSPLIT, the ozone plume located in the residual boundary layer the previous day is advected northwards by the anticyclonic circulation up to $39^{\circ} \mathrm{N}, 117^{\circ} \mathrm{E}$ (see magenta dots in Fig. 7c). At this location over the northern part of the NCP, collocated plumes of LMT ozone and $\mathrm{CO}$ are consistently observed respectively by IASI + GOME2 (Fig. 7a) and IASI (Fig. 7b). With respect to the previous day, the observed ozone concentrations remain rather high $(\sim 90 \mathrm{ppb})$, while $\mathrm{CO}$ concentrations start dropping $(\sim 270 \mathrm{ppb})$. Over northern China (north of $41^{\circ} \mathrm{N}$ ), LMT ozone is transported eastwards following a low-pressure system centred at $50^{\circ} \mathrm{N}, 140^{\circ} \mathrm{E}$ (not shown). The stratospheric filament depicted by potential vorticity at $300 \mathrm{hPa}$ east of $119^{\circ} \mathrm{E}$ (Fig. 7d) is transported southeast- 
(a)

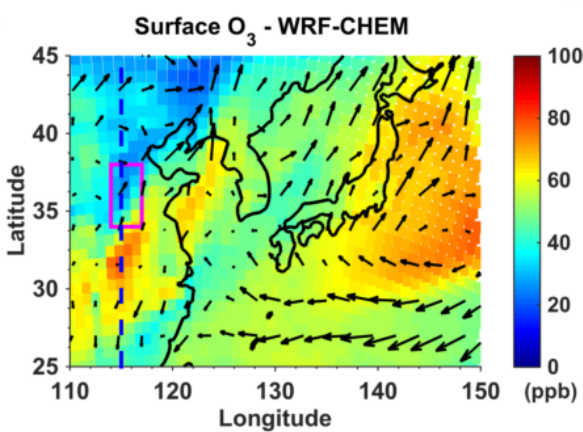

(c)

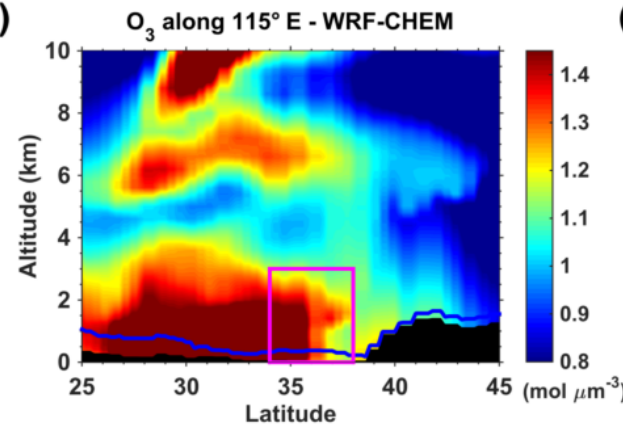

(e)

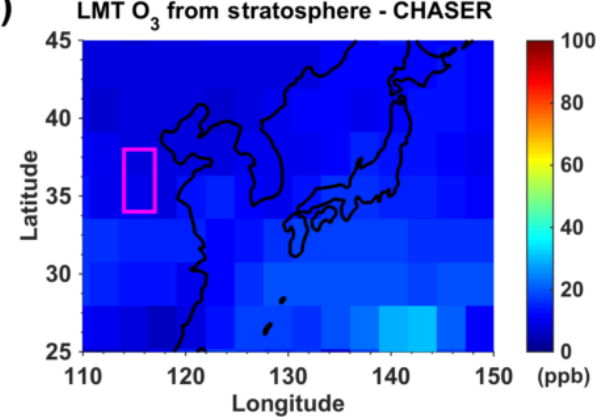

\section{May 2009}

(b)

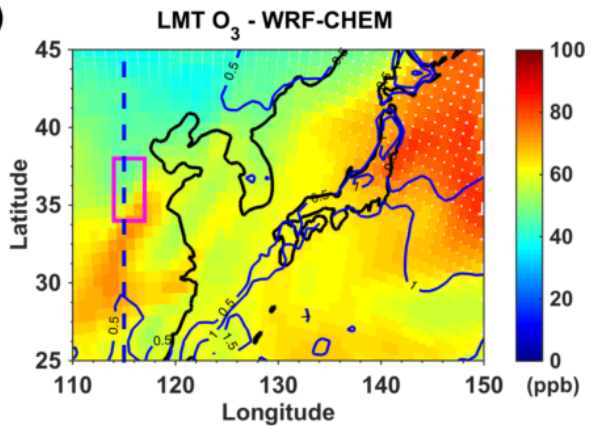

(d)

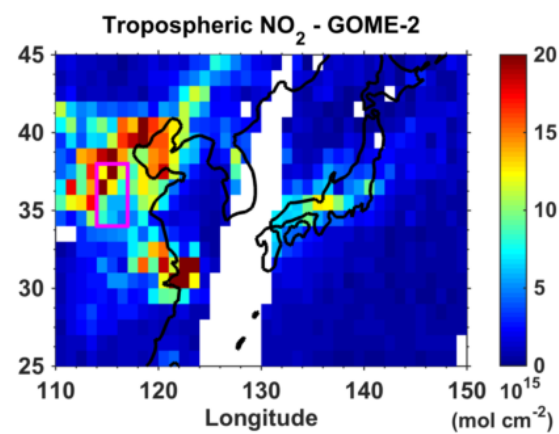

(f)

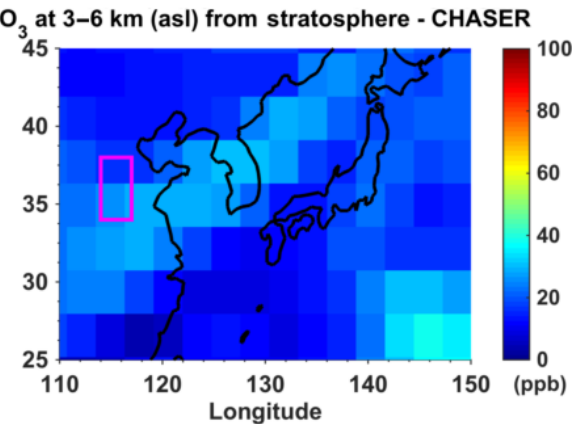

Figure 6. Ozone distribution over East Asia (a) at the surface and (b) in the LMT according to the WRF-Chem model on 3 May 2009 at 10:00 JLT. Panels (a) and (b) also show surface winds (arrows) and mixing boundary layer height (blue contours) respectively. (c) Transect of vertical profiles of tropospheric ozone burden (in mol $\mu \mathrm{m}^{-3}$ of air) along the axis $115^{\circ} \mathrm{E}$ (indicated as a dashed blue line in panel a) derived from WRF-Chem, with the mixing boundary layer height (blue) derived from ERA-I reanalysis and orography (black shading). (d) Tropospheric $\mathrm{NO}_{2}$ distribution derived from GOME-2 measurements. Stratospheric ozone reaching (e) the LMT and (f) the atmospheric layer at 3-6 km altitude, according to CHASER model simulations on 3 May 2009 at 10:00 JLT. Magenta rectangles show the locations of the air masses tracked during the pollution event in early May 2009.

wards, far from the location of the ozone plumes observed in the LMT.

\section{3 $\mathrm{O}_{3}$ plumes crossing northern China and the Korean Peninsula on 5-7 May}

The anticyclone reaches the centre of the Yellow Sea $\left(36^{\circ} \mathrm{N}\right.$, $122^{\circ} \mathrm{E}$ ) on the next day (5 May, Fig. 8c), where it remains for two more days (until 7 May). On 5 May, the CO plume observed by IASI shows an almost identical horizontal structure to the $\mathrm{O}_{3}$ plumes seen by IASI + GOME2, extending across the Yellow Sea coast from the northern part of the NCP until the northern frontier of Korea. The ozone plume originat- ing from the NCP clearly follows the anticyclonic circulation surrounding the Yellow Sea, reaching the northern coast of the Yellow Sea on 5 May (at $41^{\circ} \mathrm{N}, 124^{\circ} \mathrm{E}$; magenta rectangle in Fig. 8a).

As suggested by HYSPLIT and IASI + GOME2, the pollution plume splits into two filaments on 6 May (i.e. two clear pathways are depicted, Fig. 9a and c), one heading south towards the Korean Peninsula as entrained by the anticyclonic circulation around the Yellow Sea and the other one north of it transported by eastwards winds to northeastern China (referred to hereafter as respectively "southern" and "northern" filaments in magenta and dotted red rectangles respectively at $39^{\circ} \mathrm{N}, 127^{\circ} \mathrm{E}$ and $43^{\circ} \mathrm{N}, 130^{\circ} \mathrm{E}$; Fig. 9a). The trajectories of 

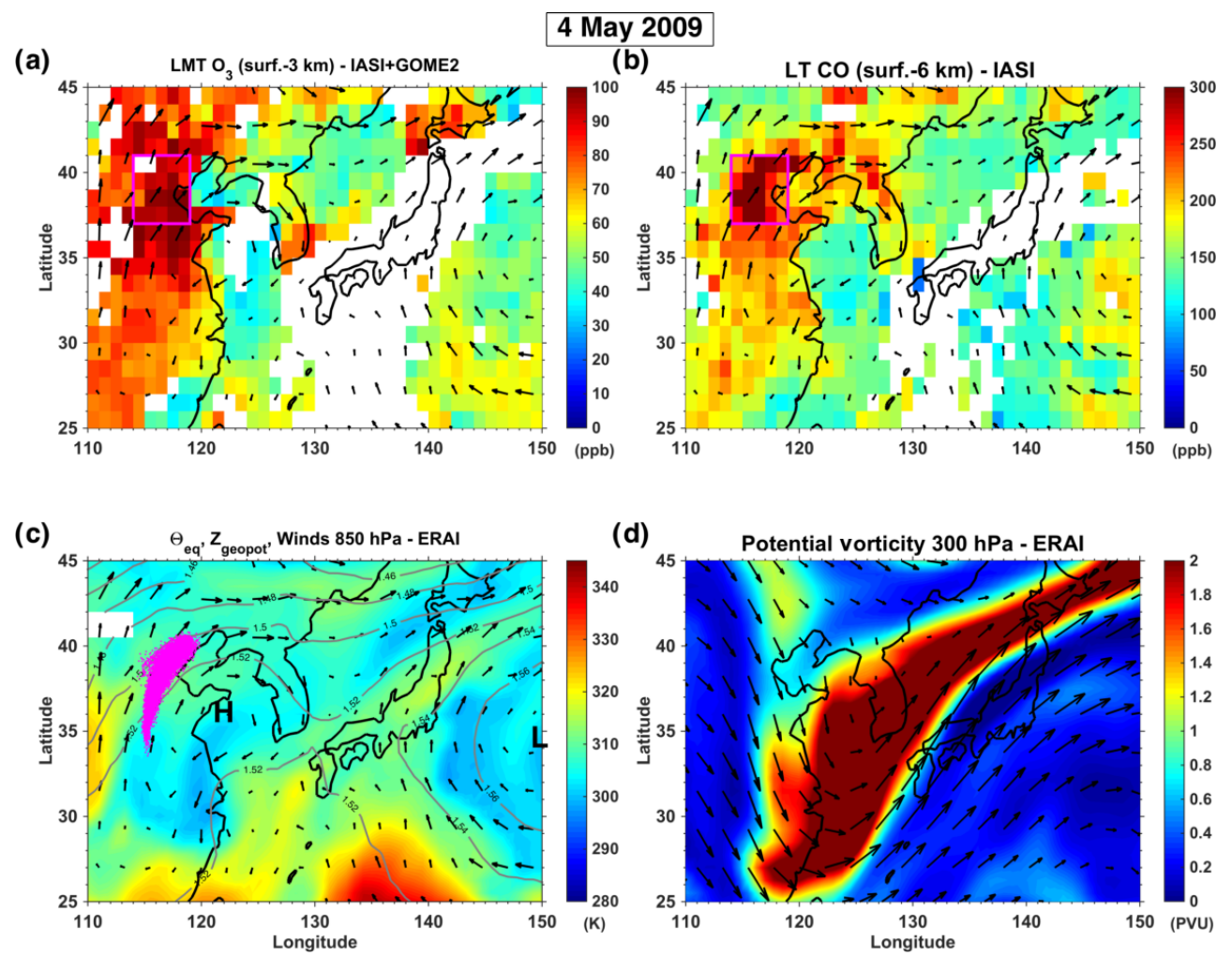

Figure 7. Same as Fig. 5 but for 4 May 2009.

the southern and northern pollution plumes (respectively magenta and red in Fig. 9) are obtained by initialising HYSPLIT respectively at the mean arrival location of the trajectories from the previous day and $2^{\circ}$ northeast from that position. The common geographical origin of the two plumes (before 6 May) is confirmed by HYSPLIT trajectories in backward mode initiated at the location of the two major ozone plumes clearly observed by IASI + GOME2 (e.g. south and north of Japan 2 days later in Fig. 12a).

Pollutants over the Korean Peninsula are carried southwards by relatively strong winds associated with a high- and a low-pressure system respectively to the west and to the east of these plumes (respectively centred at $35^{\circ} \mathrm{N}, 120^{\circ} \mathrm{E}$ and $30^{\circ} \mathrm{N}, 140^{\circ} \mathrm{E}$ in Fig. 9c). These collocated $\mathrm{O}_{3}$ and $\mathrm{CO}$ plumes show a progressive decrease in concentration with respect to the previous days (down to $\sim 220 \mathrm{ppb}$ and $\sim 70 \mathrm{ppb}$ respectively for $\mathrm{CO}$ and $\mathrm{O}_{3}$, Fig. 9). This reduction in pollutant concentrations may be induced (at least partly) by horizontal dilution during transport away from their sources.

On 7 May, the southern pollution plume over Korea elongates southwards (magenta rectangle at $37^{\circ} \mathrm{N}, 128^{\circ} \mathrm{E}$ in Fig. 10a and b), with an apparent decrease in $\mathrm{CO}$ concentrations ( $\sim 200 \mathrm{ppb}$ ). We remark that the $\mathrm{O}_{3}$ plumes over Korea (magenta rectangle) and the northeastern Chinese coast (dotted red rectangle) are probably located below $3 \mathrm{~km}$ a.s.l. as they are only clearly shown by IASI + GOME2 (Fig. 10a) and not by the IASI-only retrieval (Fig. 10e).
Over the area of the northern pollution filament (over the northeastern Chinese coast), enhancements of $\mathrm{O}_{3}$ and $\mathrm{CO}$ concentrations are shown respectively by IASI + GOME2 and IASI near $42^{\circ} \mathrm{N}, 125-132^{\circ} \mathrm{E}$ (dotted red rectangles and dots in Fig. 10a and b). This pollutant plume is observed ahead of the strong southward winds of a cold front (seen north of $42^{\circ} \mathrm{N}$ between 115 and $125^{\circ} \mathrm{E}$, violet curve in Fig. 10b), probably transporting freshly emitted pollution (as suggested by moderately enhanced $\mathrm{NO}_{2}$ concentrations at $43-45^{\circ} \mathrm{N}, 126-132^{\circ} \mathrm{E}$ up to $6 \times 10^{15} \mathrm{~mol} \mathrm{~cm}^{-2}$ in Fig. 10c). These pollutants may originate from the densely populated agglomeration around the megacity of Harbin $\left(43-46^{\circ} \mathrm{N}\right.$, $125-127^{\circ} \mathrm{E}$ ). This enhancement of pollutant concentrations along the cold front is also clearly simulated by WRF-Chem (Fig. 10d for CO), although located slightly west of the plumes depicted by the satellite retrievals (Fig. 10b). To account for this difference in the location of the plumes, the dotted red square is shifted by $4^{\circ}$ to the west in Fig. 10d with respect to the other panels. This freshly emitted or produced pollution likely mixes with the aged pollution air masses originating from the NCP. Moreover, we expect the formation of a warm conveyor belt ahead of that cold front (in violet in Fig. 10b), which typically mixes up air masses in the low atmospheric levels (as also remarked over this region on 3 May 2009, Fig. 5). Vertical mixing of freshly emitted pollutants within the LMT may also explain the enhancements of $\mathrm{O}_{3}$ and $\mathrm{CO}$ observed by the satellite approaches. 

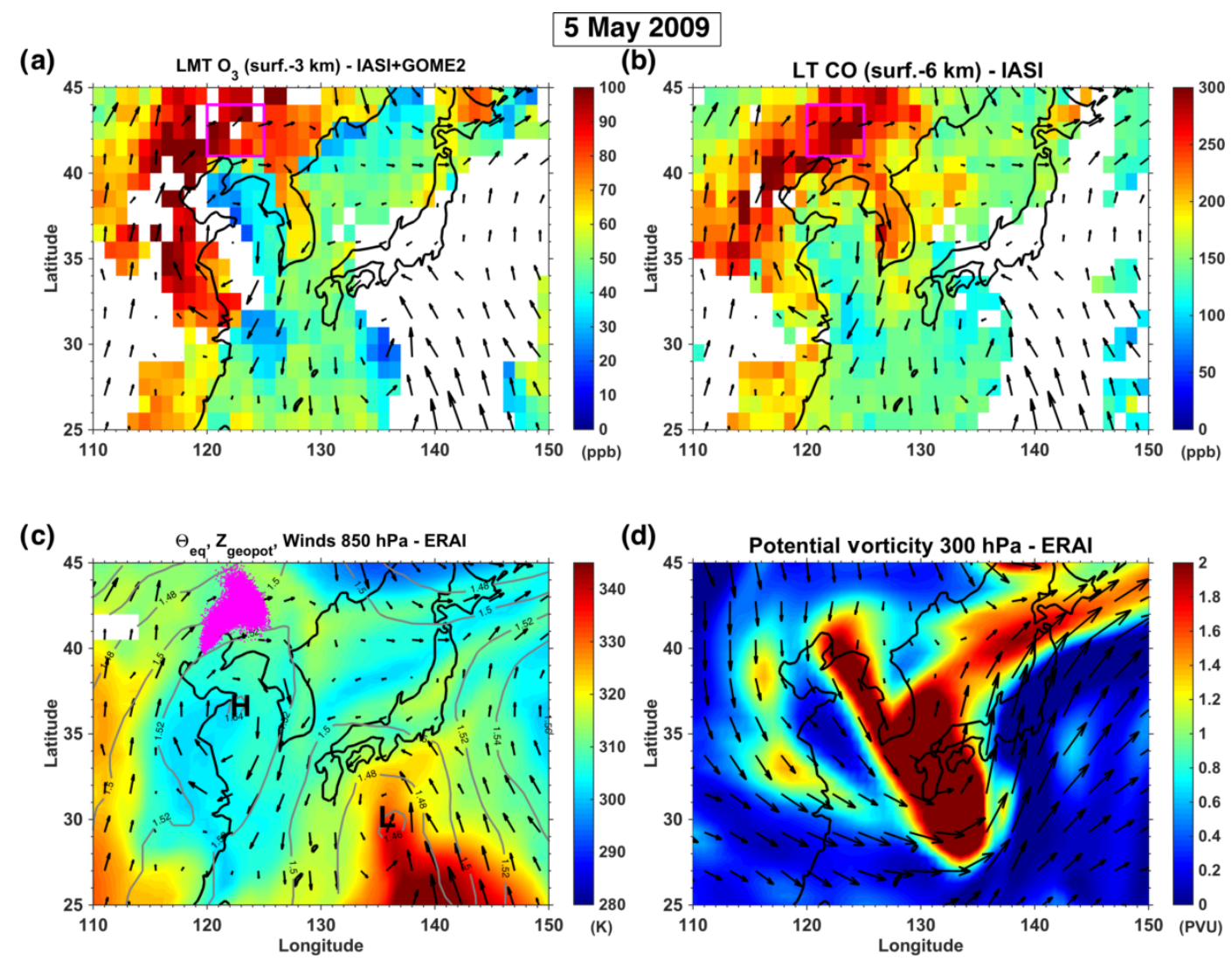

Figure 8. Same as Fig. 7 but for 5 May 2009.

Another ozone plume is observed south of the Yellow Sea on 6-7 May by IASI + GOME2 and IASI retrievals respectively in the LMT and 3-6 km a.s.l. (Figs. 9a, 10a, e). The origin of this plume is probably related to downward transport from the stratosphere, as suggested by a collocated PV filament at $300 \mathrm{hPa}$ (green contours in Fig. 10e). CHASER simulations suggest that this stratospheric ozone filament does not reach the LMT (Fig. 10f) and does not affect ozone concentrations of the tracked pollution plumes over Korea and the northeastern Chinese coast (rectangles).

\section{$3.4 \mathrm{O}_{3}$ plumes transported over Japan and the Pacific on 8-9 May}

The high-pressure system moves southwards to the East China Sea on 8 May and then eastwards until reaching the Pacific Ocean on 9 May (centred respectively at $28^{\circ} \mathrm{N}, 122^{\circ} \mathrm{E}$ in Fig. $11 \mathrm{~b}$ and $27^{\circ} \mathrm{N}, 130^{\circ} \mathrm{E}$ in Fig. 12b). The southern polluted air masses coming from Korea (magenta rectangle) are entrained by the southwards circulation on an axis around $130^{\circ} \mathrm{E}$ between the high- and low-pressure systems (Fig. 11a and b). They reach southern Japan (the island of Kyushu) on 8 May $\left(31^{\circ} \mathrm{N}, 130^{\circ} \mathrm{E}\right.$ in Fig. 11a) and the Pacific on 9 May $\left(27^{\circ} \mathrm{N}, 130^{\circ} \mathrm{E}\right.$ in Fig. 12a). As only captured by IASI + GOME2 (Fig. 11a) and not by IASI (Fig. 11c), the moderately high $\mathrm{O}_{3}$ concentrations over the island of Kyushu are probably located below $3 \mathrm{~km}$ a.s.l. Ozone and carbon monoxide concentrations at the location depicted by HYSPLIT (magenta rectangles) are rather close to the background levels (particularly for $\mathrm{CO}$ ).

The northern $\mathrm{O}_{3}$ plume coming from the northeastern Chinese coast is transported over the Sea of Japan by strong anticlockwise winds around the low-pressure system east of Japan on 8 May (Fig. 11a) until reaching the Pacific southeast of Japan on 9 May (Fig. 12a). This ozone plume is likely located in the LMT, as clearly depicted by IASI + GOME2 and not by IASI (red rectangles respectively in Fig. 11a and c). According to CHASER and low PV at $300 \mathrm{hPa}$, we do not expect a significant contribution of stratospheric ozone reaching the LMT over the Sea of Japan on 8 May (Fig. 11e and $f$ ) or over central Japan on 9 May (Fig. 12e and f). Therefore, these ozone plumes in the LMT are likely associated with photochemical production during transport from precursors emitted over land (from northeastern China on 7 May and Japan on 8 May). Simulations from WRF-Chem also suggest significant photochemical production of LMT ozone during transport from northeastern China to central Japan and the Pacific (see Sect. 4).

Downward transport of stratospheric ozone occurs southeast of Japan on 8-9 May, as suggested by the location of 

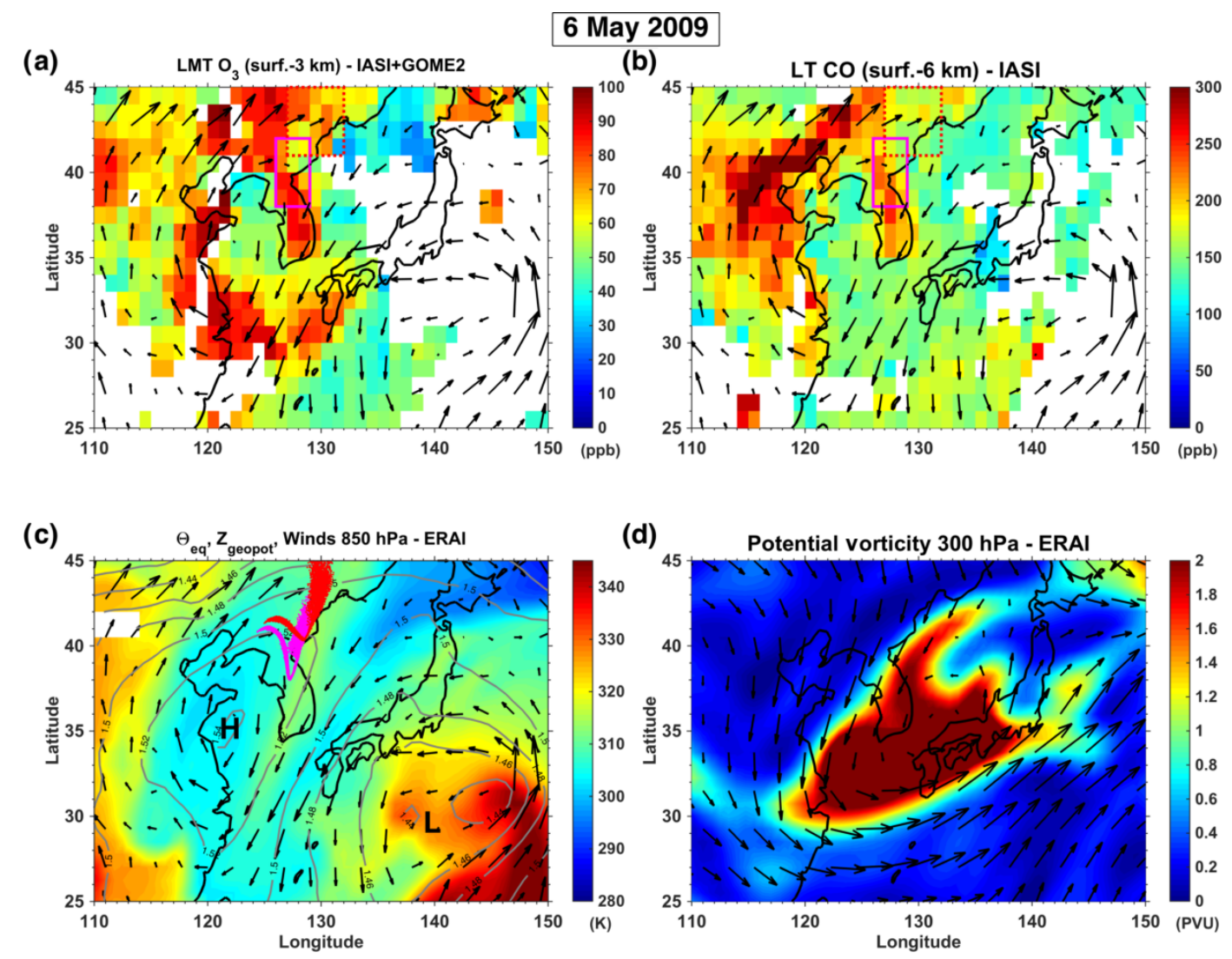

Figure 9. Same as Fig. 7 but for 6 May 2009. In panels (a) and (b), magenta and dotted red squares show the main location of the southern and northern pollution filaments respectively. Dots in panel (c) indicate the location of the air parcels tracked with the HYSPLIT dispersion model, in magenta and red (southern and northern pollution plumes respectively).

the PV filament at $300 \mathrm{hPa}$ (Figs. 11e and 12e), which travels eastwards (located south of the Yellow Sea on 7 May). This ozone plume originating from the stratosphere reaches the lower troposphere above $3 \mathrm{~km}$ a.s.l. (as observed by both IASI + GOME2 and IASI in Figs. 11a and c, and 12a and c) but not the LMT (indicated by CHASER in Figs. 11f and 12f). This suggests distinct origins and vertical locations for the two elongated ozone plumes southeast of Japan observed by IASI + GOME2 on 9 May $\left(27-40^{\circ} \mathrm{N}, 132-141^{\circ} \mathrm{E}\right.$ in Fig. 12a). The one closer to Japan is associated with photochemical production, and the other one with stratospheric transport (indicated by green contours of PV in Fig. 12e), respectively located in the LMT and at 3-6 kma.s.l.

\section{Photochemical production of lowermost tropospheric ozone during transport}

According to the previous section, the major ozone outbreak initiated over the NCP in the afternoon of 2 May 2009 is transported northeastwards over northern China; it splits into two pollution filaments and then heads southwards until reaching southern Japan on 9 May 2009. Detailed anal- yses of the transport pathways of this large pollution plume (highlighted in magenta and dotted red rectangles in Figs. 4-12) suggest two significant contributions of ozone precursors from the NCP (2 May) and northeastern China (northern pollution filament on 7 May). We do not observe any significant contribution of ozone from the stratosphere collocated with these ozone plumes nor mixing with large ozone plumes formed in other regions. In absence of local production (which occurs on 2 May and for the northern plume on 7 May), we expect the evolution of LMT ozone to be mainly driven by either production during transport (linked with the availability of ozone precursors and solar insolation) or dilution of the air masses (due to horizontal wind divergence and/or vertical mixing).

Figures 13 and 14 present a quantitative analysis of the Lagrangian evolution of the air masses travelling on 3-9 May 2009 across East Asia from the NCP to southern Japan. These time series show the daily evolution of a given variable averaged at the location of the highlighted major pollutant plume, as depicted by the HYSPLIT dispersion model (magenta and dotted red rectangles in Figs. 4-12), each day during the morning (at the time of overpass of the MetOpA satellite around 09:30 local time). The key variable to anal- 
(a)

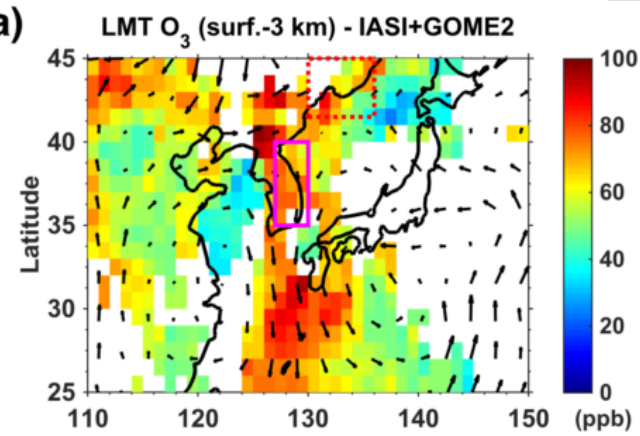

(c)

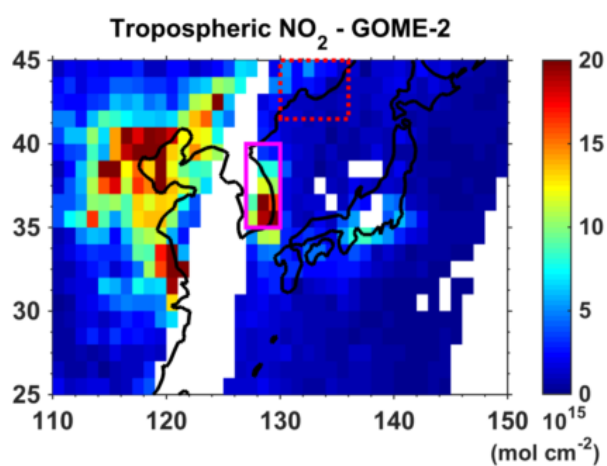

(e)

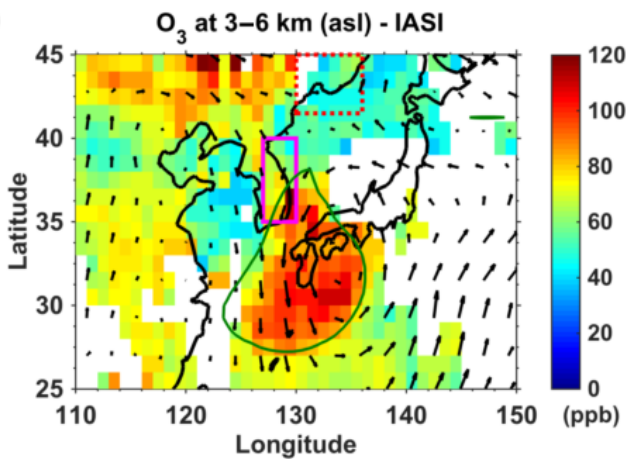

\section{May 2009}

(b)

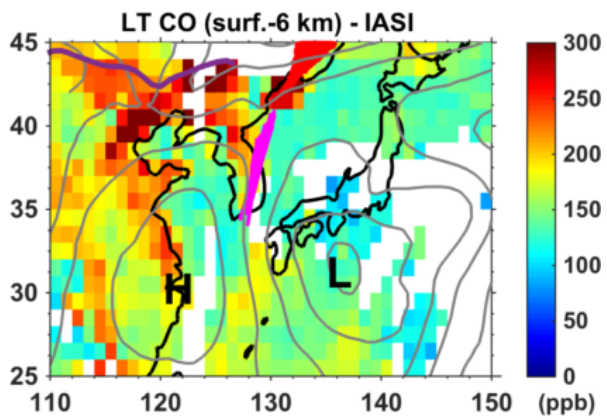

(d)

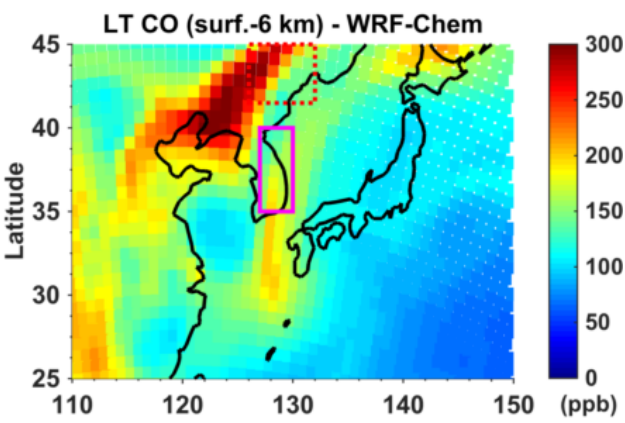

(f)

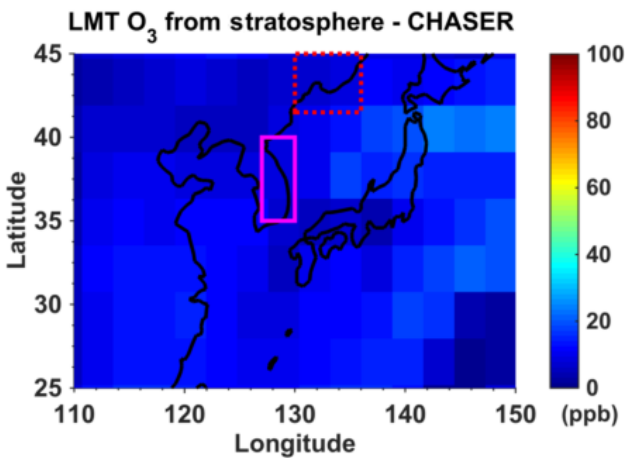

Figure 10. Same as Fig. 7 for panels (a) and (b) but for 7 May 2009. (c) Tropospheric $\mathrm{NO}_{2}$ distribution derived from GOME-2 measurements . (d) LT CO distribution according to WRF-Chem model. (e) Tropospheric ozone from 3 to $6 \mathrm{~km}$ altitude derived from IASI, winds at $700 \mathrm{hPa}$ and potential vorticity at $300 \mathrm{hPa}$ contours (2 PVU in green) from ERA-I. (f) Stratospheric ozone reaching the LMT according to CHASER model simulations. Panel (b) also shows geopotential heights at $850 \mathrm{hPa}$ from ERA-I (grey contours every $200 \mathrm{~m}$ ) and the location for 7 May 2009 of the polluted tracked air masses derived from HYSPLIT (magenta and red dots for the southern and northern pollution filaments respectively). For WRF-Chem (d), the northern pollution plume (dotted red square) is shifted $4^{\circ}$ to the west, in order to account for the difference in its location between the model and satellite observations. The location of a cold front is shown by a violet curve in panel (b).

yse is the ratio $\Delta \mathrm{O}_{3} / \Delta \mathrm{CO}$, which describes the relative production or decrease of $\mathrm{O}_{3}$ with respect to $\mathrm{CO}$, during transport (e.g. Price et al., 2004) or at given fixed locations (e.g. Chin et al., 1994). Figure 13a-c shows two curves, one corresponding to the beginning of the event and the southern filament of pollution and the other for the northern pollution filament (i.e. curves respectively in magenta and dotted red).

\subsection{Southern pollution plume}

For the southern filament, a sustained increase of the ratio $\Delta \mathrm{O}_{3} / \Delta \mathrm{CO}$ is clearly derived during the whole ozone outbreak across East Asia from satellite observations (Fig. 13a). It evolves from $\sim 0.25$ over the NCP on 3 May to $\sim 0.46$ on 8-9 May over the Pacific and southern Japan (in magenta in Fig. 13a). As dilution of the air masses affects equally the concentrations of both pollutants, a monotonous enhancement of $\Delta \mathrm{O}_{3} / \Delta \mathrm{CO}$ is clear evidence of the production of 


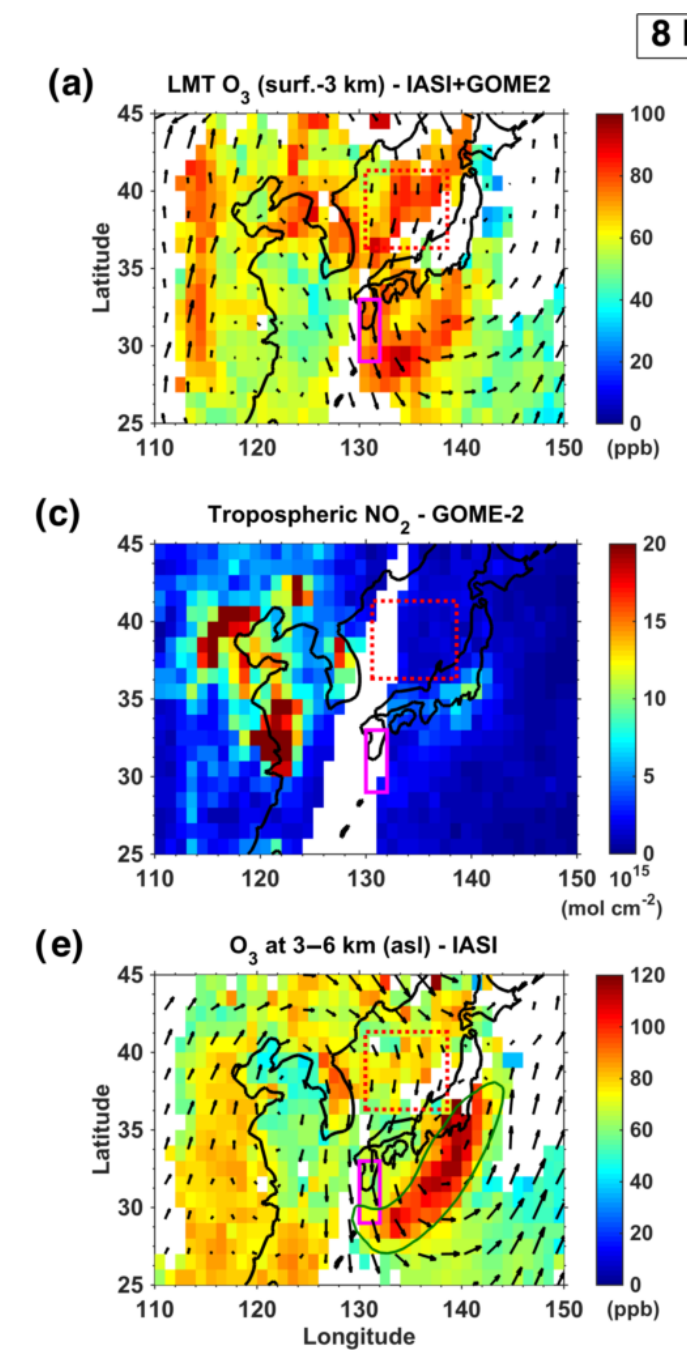

8 May 2009

(b)

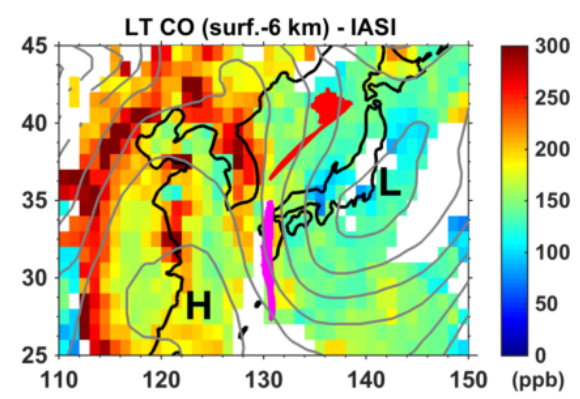

(d)

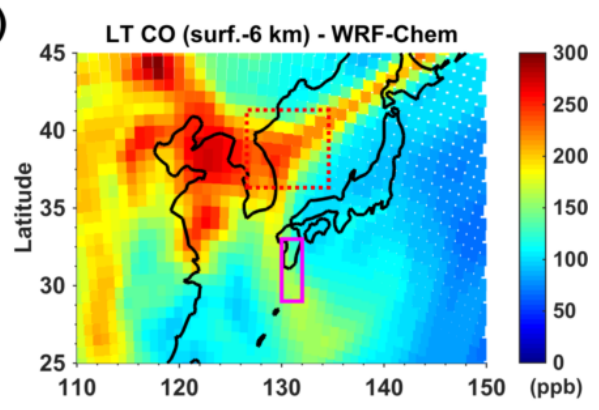

(f)

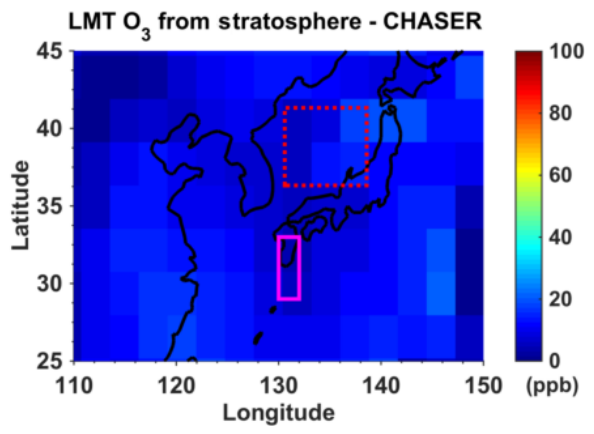

Figure 11. Same as Fig. 10 but for 8 May 2009.

$\mathrm{O}_{3}$ during transport. The evolution of this ratio from 0.25 over the main source regions to 0.46 after long-range transport estimated here with satellite retrievals is consistent with other estimations from airborne in situ measurements ranging from 0.2 to 0.5 (from flights at $2-3 \mathrm{~km}$ altitude) for other events of trans-Pacific long-range transport of industrial/urban pollution and in absence of stratospheric intrusions (Price et al., 2004). Overall consistency is also found with model estimates of 0.3 for typical air masses downwind from Asian pollution sources in springtime (Mauzerall et al., 2000 ) and the same value from in situ ground-based measurements over the United States in summer (Chin et al., 1994). These IASI + GOME2 $\mathrm{O}_{3}$ and IASI CO values are fairly higher than those estimated in the lower troposphere with IASI-only $\mathrm{O}_{3}$ retrievals $(0.16-0.28$ for the column below $6 \mathrm{~km}$ a.s.l.) for an East Asian pollution event in May 2008 (Dufour et al., 2015) and lower than retrievals in the free troposphere $(400-700 \mathrm{hPa})$ from OMI and AIRS $(\sim 0.6)$ over Tokyo (Kim et al., 2013).
Assuming that most $\mathrm{CO}$ is emitted at the beginning of the event (for the southern filament, magenta curve in Fig. 13a), the evolution of the $\Delta \mathrm{O}_{3} / \Delta \mathrm{CO}$ values suggests a production of $\mathrm{O}_{3}$ during transport of $\sim 60 \%$ after the first 3 days (mainly over northern China and Korea) and of $\sim 84 \%$ during the whole event (6 days) with respect to that over the NCP. In this case, the greatest growth of $\Delta \mathrm{O}_{3} / \Delta \mathrm{CO}$ occurs on 3-6 May when the air masses are transported over the most industrialised areas (the NCP and northern China) with the greatest emissions of ozone precursors as $\mathrm{NO}_{x}$ (as shown in Fig. 10c for $\mathrm{NO}_{2}$ ). In the following days, a slower growth with almost constant $\Delta \mathrm{O}_{3} / \Delta \mathrm{CO}$ occurs over the Korean Peninsula (on 7 May), southern Japan (8 May) and the Pacific (9 May), far from the main sources of $\mathrm{O}_{3}$ precursors over China. Less ozone production over this oceanic region is consistent with low availability of $\mathrm{NO}_{2}$, indicated by satellite observations and both models (Fig. 14j), and a regime of $\mathrm{NO}_{x}$-limited photochemical production of $\mathrm{O}_{3}$, as observed over Fukue Island (Kanaya et al., 2016). This behaviour is 


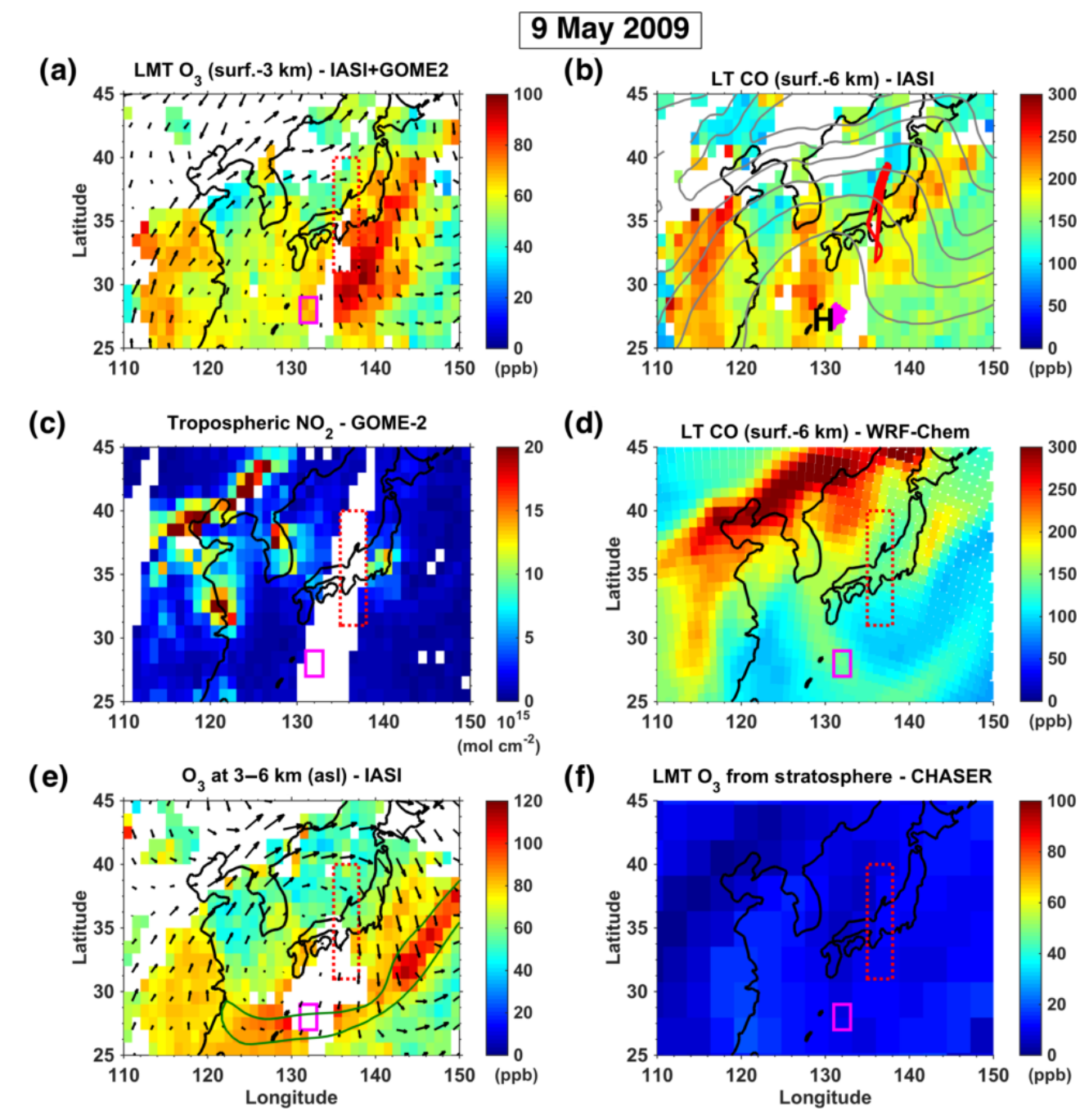

Figure 12. Same as Fig. 10 but for 9 May 2009. Here, no shift is considered for the location of the northern pollution plume (dotted red square) in WRF-Chem simulations, with respect to that of satellite observations.

also simulated by WRF-Chem and CHASER, showing ozone diurnal cycles with greater ozone production in the afternoon of the first 3 days of the event and significantly less thereafter (see hourly outputs of the models in Fig. 14a and c). Simulated diurnal cycles of ozone also reveal the strong nocturnal reduction in ozone concentrations (down to 30-40 ppb for WRF-Chem and 40-60 ppb for CHASER, dotted light colour curves in Fig. 14a and c), particularly significant over China (3-6 May), probably associated with nitrogen monoxide (NO) titration over the continent, and less pronounced thereafter, near or over the ocean. Moreover, WRF-Chem clearly suggests a reduction in $\mathrm{CO}$ concentrations (also observed by IASI in the lower troposphere), particularly significant after 6 May (Fig. 14b) and likely linked to atmospheric dilution (horizontal and/or vertical). Sinks of CO are not expected to be significant during a period of 3 days.

The $\Delta \mathrm{O}_{3} / \Delta \mathrm{CO}$ ratios derived from the CHASER and WRF-Chem models in the LMT follow a similar relative evo- lution to that from satellite retrievals, with a minimum at the beginning of the event and a relative monotonous increase by the end (Fig. 13b and c). This is particularly observed for WRF-Chem and until 6 May for CHASER. In absolute values, the ratio $\Delta \mathrm{O}_{3} / \Delta \mathrm{CO}$ derived from the satellite measurements is higher than that from models. At the beginning of the event (3-5 May), satellite estimates of the ratio are 0.1 to 0.15 higher than those from models. After 6 May, satellite and WRF-Chem ratios are closer (with differences between 0.05 and 0.1 ). Differences between the models and with respect to satellite-derived $\Delta \mathrm{O}_{3} / \Delta \mathrm{CO}$ ratios are likely associated with photochemical schemes in the models, model resolutions, precursors availability, the location of the plumes etc. The non-steady enhancement of $\Delta \mathrm{O}_{3} / \Delta \mathrm{CO}$ for CHASER after 6 May could be partly associated with significantly less availability of $\mathrm{NO}_{2}$ in the LMT, as compared to WRF-Chem (a factor of 3 higher, Fig. 14i) and a less marked reduction of 
(a)

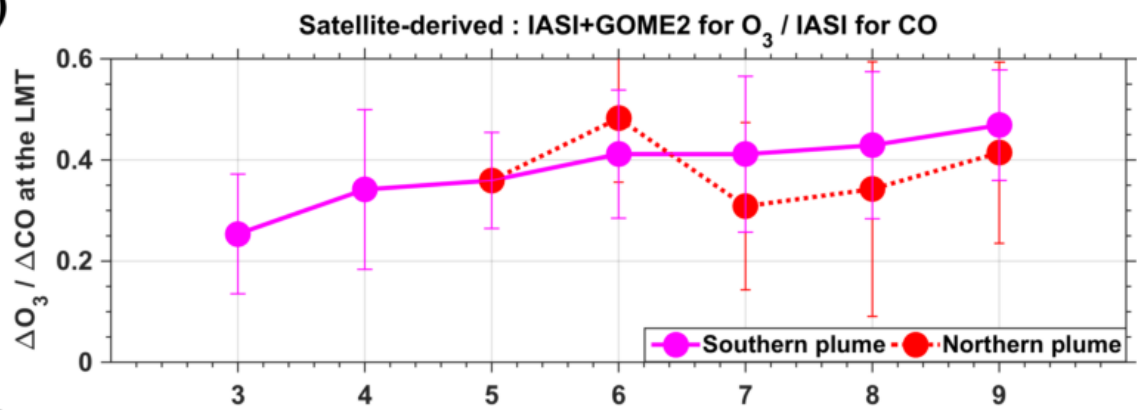

(b)

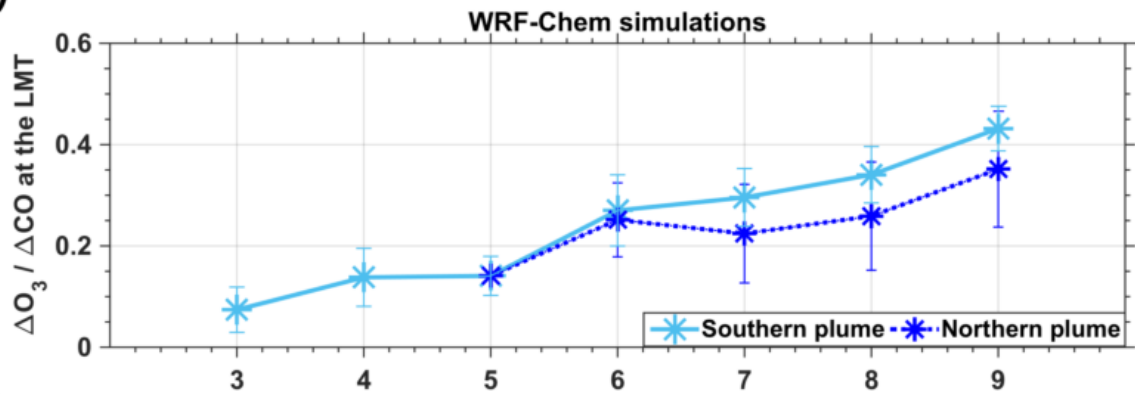

(c)

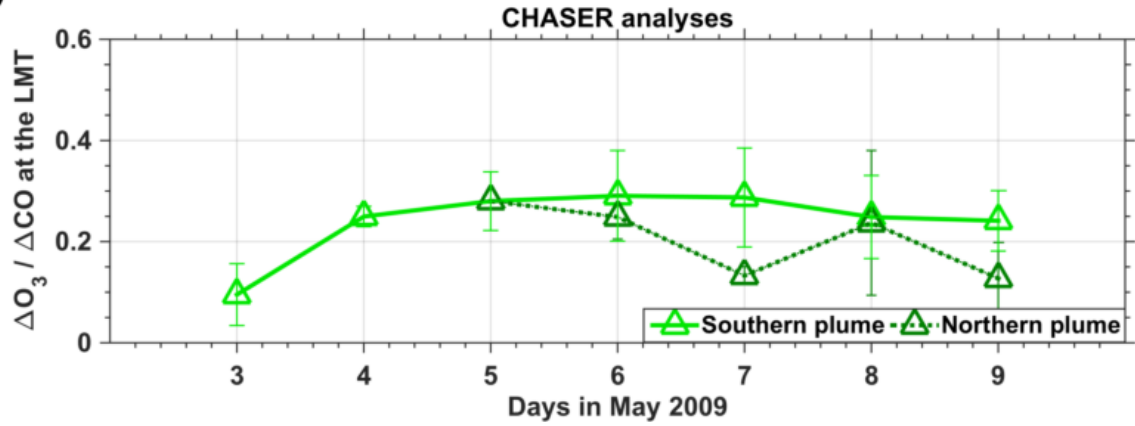

Figure 13. Lagrangian evolution of ozone enhancement during transport described by the ratio $\Delta \mathrm{O}_{3} / \Delta \mathrm{CO}$ in the LMT for the two pollution plumes tracked across East Asia from 3 to 9 May 2009, derived from (a) IASI + GOME2 $\mathrm{O}_{3}$ and IASI CO satellite retrievals, (b) WRF-Chem simulations and (c) CHASER analyses. Ratios of $\Delta \mathrm{O}_{3} / \Delta \mathrm{CO}$ for the southern (northern) pollution plumes are plotted in magenta (dotted red), light blue (dotted blue) and light green (dotted green) in respectively panels (a), (b) and (c). Curves show mean and SDs ( \pm vertical bars) of $\Delta \mathrm{O}_{3} / \Delta \mathrm{CO}$ over the areas depicted by rectangles in Figs. 5 and 7-11 for each of the days of the pollution outbreak.

CO concentrations in the LMT (while it clearly decreases for WRF-Chem, Fig. 14b and d).

Figure $14 \mathrm{~g}$ and $\mathrm{h}$ show that the steady increase of $\Delta \mathrm{O}_{3} / \Delta \mathrm{CO}$ observed for the southern pollution plume does not seem to be linked to changes in sensitivities of the satellite retrievals. This is described in terms of the degrees of freedom and the altitude of maximum sensitivity of the retrieved atmospheric columns, which respectively quantify the amount of information provided by the satellite retrieval and the altitude it comes from. Neither of these two variables for either $\mathrm{O}_{3}$ or $\mathrm{CO}$ reflect such a steady variation, greater during the first 3 days and nearly flat afterwards, as that observed for $\Delta \mathrm{O}_{3} / \Delta \mathrm{CO}$. The LMT $\mathrm{O}_{3}$ retrieval sensitivity peaks between 2.5 and $3 \mathrm{~km}$ a.s.l. for most of the days (and near $4 \mathrm{~km}$ a.s.l. over oceanic cold waters on 9 May), with degrees of freedom fluctuating from 0.2 to 0.3 (for the LMT,
Fig. $14 \mathrm{~g}$, and around 5.5 to the $\mathrm{O}_{3}$ total column, not shown). The CO lower tropospheric column is retrieved with 0.8 to 1 DOF with a peak of sensitivity from 3.5 to $5 \mathrm{~km}$ altitude (Fig. 14g and h).

Figure $14 \mathrm{e}, \mathrm{f}$ and i show evidence of the negligible influence of stratospheric ozone on the evolution of $\Delta \mathrm{O}_{3} / \Delta \mathrm{CO}$ in the LMT for the polluted air masses tracked on 3-9 May. Ozone amounts within the LMT originating from the troposphere are a factor of $\sim 12$ greater than the contribution from the stratosphere, according to CHASER simulations (accounting or not accounting for stratospheric contributions, Fig. 14e). This is consistent with meteorological tracers of stratospheric air masses, such as the potential vorticity at $500 \mathrm{hPa}$ (Fig. 14i). At this pressure level, no particular enhancement of potential vorticity is clearly remarked in correlation with the days of high concentration of ozone in the 

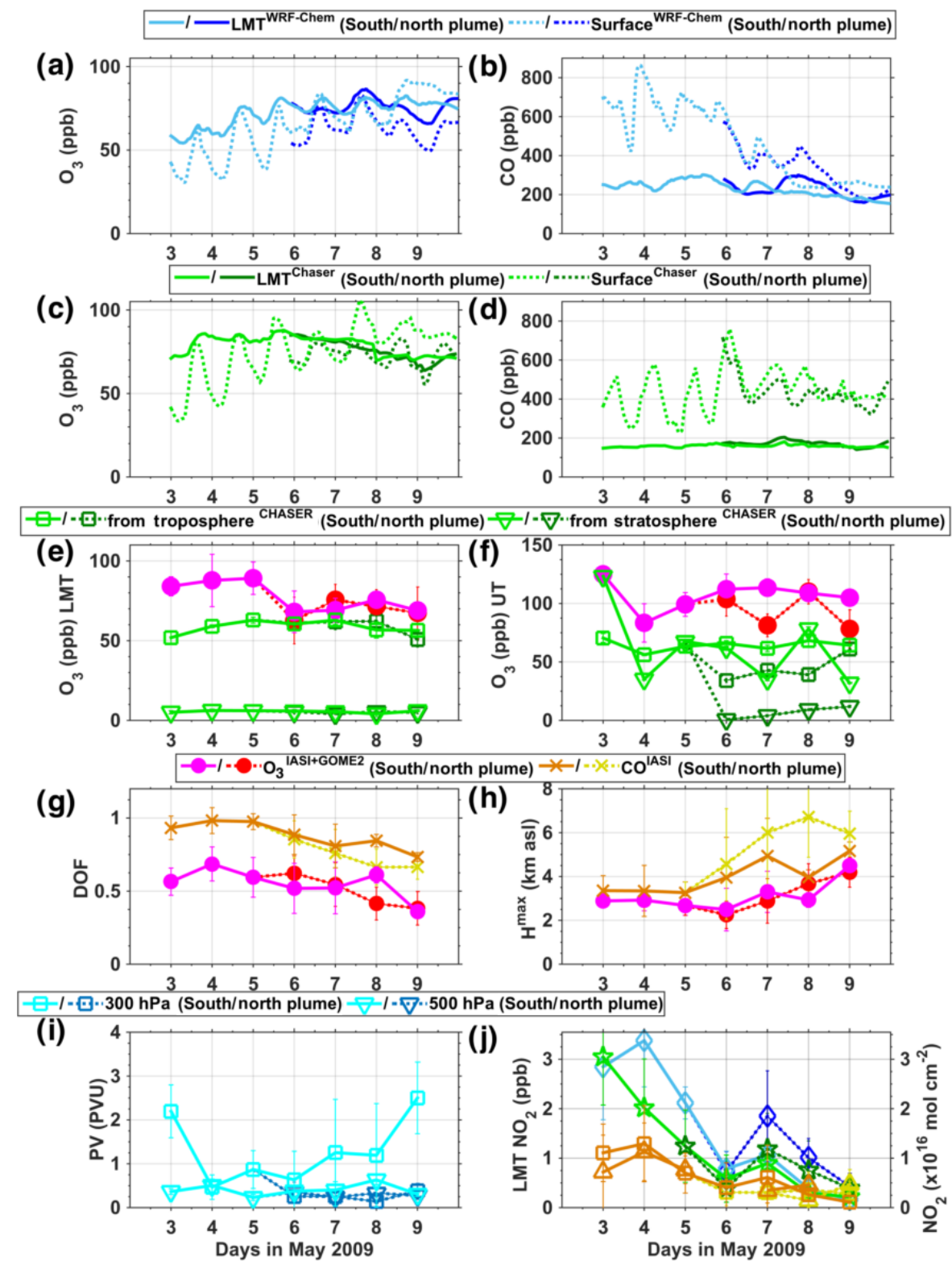

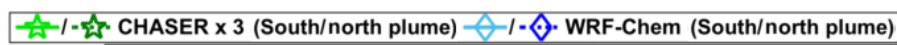
-I- GOME2 09:30 LT (S./N.plume) $\triangle-I-\triangle$ OMI 13:30 LT (S./N. plume)

Figure 14. Lagrangian evolution at the location of the pollution plumes across East Asia (rectangles in Figs. 5 and 7-11) on 3-9 May 2009 for the following variables: (a, c) $\mathrm{O}_{3}$ and (b, d) CO mixing ratios in the LMT (plain lines) and the surface (dotted lines) from WRF-Chem (panels $\mathbf{a}$ and $\mathbf{b}$ ) and CHASER analysis (panels $\mathbf{c}$ and $\mathbf{d}$ ), for the southern (lighter colours) and northern (darker colours) pollution plumes. Ozone burden in the (e) LMT and the (f) upper troposphere (UT), observed by IASI + GOME2 (magenta and red for the southern and northern plumes respectively) and simulated by CHASER for air masses originating from the troposphere (squares) and stratosphere (triangles). Satellite retrieval sensitivity in term of (g) degrees of freedom and (h) heights of maximum sensitivity in the LMT and LT for respectively IASI + GOME2 and IASI. In panel (g), DOF for IASI + GOME2 are multiplied by a factor of 2 for visual clarity. (i) Potential vorticity at 300 (squares) and $500 \mathrm{hPa}$ (triangles) from ERA-I reanalysis. (j) $\mathrm{NO}_{2}$ concentrations observed as total columns by GOME-2 at 09:30 JLT (squares) and OMI at 13:30 JLT (triangles) and derived from WRF-Chem (ovals) and CHASER analyses (stars, multiplied by a factor of 3 for visual clarity) in the LMT at 10:00 JLT. In panels (e-j), curves with lighter and darker colours but the same marker correspond to respectively the southern and northern pollution plumes. We show mean values and SDs ( \pm vertical bars) over the areas depicted by rectangles in Figs. 5 and 7-11 for each of the days of the pollution outbreak. 
LMT. On the other hand, the ozone contribution of stratospheric downward transport in the upper troposphere (from 6 to $12 \mathrm{kma.s.1}$.) fluctuates significantly during the whole event (Fig. 14f). Potential vorticity on 3 May 2009 is high only at $300 \mathrm{hPa}$ in consistency with an ozone enhancement in the upper troposphere (Fig. 14e), but not below (see potential vorticity at $500 \mathrm{hPa}$ in Fig. 14i). As a quality check, we remark that similar concentrations of ozone in the LMT and the upper troposphere are retrieved by IASI + GOME2 and simulated by CHASER (adding in contributions from the troposphere and stratosphere) averaged over the whole event (differences of $13 \mathrm{ppb}$ at most).

\subsection{Northern pollution plume}

For the northern pollution plume, satellite-derived $\Delta \mathrm{O}_{3} / \Delta \mathrm{CO}$ ratios show an increase on 6 May (curve red in Fig. 13a) with respect to the previous days, as remarked for the southern plume. On 7 May, the eastern plume air masses exhibit lower $\Delta \mathrm{O}_{3} / \Delta \mathrm{CO}$ ratios of $\sim 0.25$, probably due to mixing with freshly emitted pollutants from the northern China megacities (suggested by $\mathrm{CO}$ observations on 7 May, Fig. 10b, and $\mathrm{NO}_{2}$ concentrations from WRF-Chem and CHASER in Fig. 14j). This value of $\Delta \mathrm{O}_{3} / \Delta \mathrm{CO}$ is practically the same as the one observed on 3 May over large pollution sources from NCP. From 7 to 9 May, the $\Delta \mathrm{O}_{3} / \Delta \mathrm{CO}$ ratio (in red) rises up monotonically from $\sim 0.25$ to $\sim 0.4$, thus suggesting photochemical production during transport (as remarked for the days following emission of ozone precursors over the NCP). This evolution in terms of $\Delta \mathrm{O}_{3} / \triangle \mathrm{CO}$ ratios corresponds to an ozone production of about $\sim 60 \%$ with respect to that on 7 May, within 2 days. The relative evolution of satellite-derived $\Delta \mathrm{O}_{3} / \Delta \mathrm{CO}$ ratios is consistent with WRF-Chem simulations (blue curve in Fig. 13b), which also show a relative increase from 5 to 6 May and then lower values on 7 May (with an additional pollution plume) that rise up monotonically until 9 May. The CHASER model shows an enhancement from 7 to 8 May, but it drops on 9 May (Fig. 13c). The latter might be linked to low availability of $\mathrm{NO}_{2}$ in the LMT in CHASER simulations (a factor of 3 lower than for WRF-Chem, Fig. 14j) and eventually a difficulty to represent such small-scale pollution plumes with the coarser resolution of this global model.

During this period, air masses are transported from northeastern China to the Sea of Japan and then over central Japan, finally reaching the Pacific. Ozone precursors might originate from northeastern Chinese and central Japanese megacities. Both WRF-Chem and CHASER simulations suggest a relatively higher availability of $\mathrm{NO}_{2}$ in the LMT (although 3 times higher for WRF-Chem) for the northern pollution filament (dotted curves with respectively blue ovals and green stars in Fig. 14j) than for the southern plume (light blue and light green in Fig. 14j). This is consistent with the greater growth of $\Delta \mathrm{O}_{3} / \Delta \mathrm{CO}$ (and therefore ozone production) from
7 to 9 May for the northern pollution plume with respect to that at the south, as estimated with satellite retrievals (Fig. 13a). WRF-Chem and CHASER simulations also suggest the occurrence of ozone production during transport after 7 May by a succession of marked diurnal cycles of ozone with greater amounts in the afternoon (Fig. 14a and c). As compared to the period before 6 May, ozone diurnal cycles simulated by both models exhibit smaller amplitudes, which are likely associated with less nighttime titration over noncontinental areas. The reduction of this ozone reservoir may also enhance the growth of $\Delta \mathrm{O}_{3} / \Delta \mathrm{CO}$ during transport.

As for the southern plume, stratospheric contribution of ozone down to the LMT at the location of the northern pollution filament seems negligible according to CHASER simulations (Fig. 14e) and low values of potential vorticity (Fig. 14i). Furthermore, satellite-derived $\Delta \mathrm{O}_{3} / \Delta \mathrm{CO}$ ratios may be affected by changes in sensitivity for the CO IASI retrievals, which peaks at the middle troposphere on 7-8 May, instead of the lower troposphere (Fig. 14h). According to sensitivity analyses, these uncertainties induce under- or overestimations for $\Delta \mathrm{O}_{3} / \Delta \mathrm{CO}$ that remain below $\pm 11 \%$ for changes of 1 and $3 \mathrm{~km}$ at the heights of maximum sensitivity for respectively $\mathrm{O}_{3}$ and $\mathrm{CO}$ retrievals. These estimations are obtained using typical vertical profiles of $\mathrm{O}_{3}$ and $\mathrm{CO}$ for a pollution plume (from WRF-Chem) smoothed with averaging kernels of the satellite retrievals and taking into account the concomitant change in the heights of maximum sensitivity for $\mathrm{O}_{3}$ and $\mathrm{CO}$ retrievals, as in both cases they depend on the difference between surface and air temperatures. These uncertainties are significantly lower than changes observed for $\Delta \mathrm{O}_{3} / \Delta \mathrm{CO}$ from satellite retrievals (up to $84 \%$ during the whole event). Therefore, conclusions drawn on the occurrence and quantification of photochemical ozone production in this period are not significantly affected by changes in satellite retrieval sensitivities.

\section{Summary and conclusions}

We have presented a detailed study of the daily evolution of lowermost tropospheric ozone during a major pollution outbreak across East Asia in early May 2009, by means of IASI + GOME2 multispectral satellite observations and chemistry-transport models. This new multispectral satellite approach offers the currently unique capacity to observe the ozone distribution in the lowermost troposphere (below $3 \mathrm{~km}$ a.s.l.) with a maximum of sensitivity down to $2 \mathrm{~km}$ a.s.l. over land. Comparison with respect to ozonesonde measurements shows a good performance of IASI + GOME2 in retrieving ozone in the LMT on average for 46 locations in all seasons on all continents around the world (mean bias of $\sim 3 \%$, correlation of 0.85 and mean precision of $16 \%$ ), and particularly over East Asia (where the present analysis is focused). Comparisons with surface in situ measurements illustrate as well the very good performance of 
IASI + GOME2 in observing ozone pollution from space. Contrary to IASI alone, IASI+ GOME2 is capable of observing the spatiotemporal variability of surface ozone during the two main pollution events in springtime 2009 over the Japanese islands, with relatively low bias (5\%) and a fair correlation (0.69).

Using IASI + GOME2, we describe the transport pathways and daily evolution of the ozone pollution outbreak in the lowermost troposphere across East Asia in early May 2009, with unprecedented observational detail. We document the transport pathways of ozone and carbon monoxide plumes in the lowermost troposphere from the North China Plain to the Pacific, surrounding the Yellow Sea and passing over Korea and Japan. Model simulations suggest that these plumes are formed near the surface on 2 May, mixed within the mixing boundary layer over the lowermost troposphere (up to $3 \mathrm{~km}$ a.s.l.) during the day and then transported as a residual boundary layer in the following days until reaching the Pacific on 9 May. Satellite retrievals depict clearly concomitant structures of LMT $\mathrm{O}_{3}$ and $\mathrm{CO}$ plumes almost every day, thus suggesting the anthropogenic origin of both pollutants. Within the pollution plumes, $\mathrm{LMT} \mathrm{O}_{3}$ mixing ratios range from $\sim 90 \mathrm{ppb}$ at the beginning of the event to $\sim 70 \mathrm{ppb}$ at the end. During the event, ozone concentration is affected simultaneously by both photochemical production within transported air parcels and horizontal/vertical dilution associated with atmospheric circulation. We estimate that the contribution of photochemical production is an increase of up to $84 \%$ of ozone amounts with respect to that produced on the first day of the event over NCP. This estimation uses $\mathrm{O}_{3}$ to-CO enhancement ratios with respect to background levels for the pollution plumes transported across East Asia. The evolution of this ratio is influenced by sources or sinks of pollutants and not by atmospheric dilution, as the latter affects equally both pollutants. This type of result represents a strong benchmark for atmospheric pollution models. It has been shown that the two models used here (CHASER and WRF-Chem) are able to reproduce the broad features of the temporal evolution of the enhancement ratio. The absence of stratospheric ozone contributions confirms the photochemical origin of $\mathrm{O}_{3}$ enhancements with respect to those of $\mathrm{CO}$. Moreover, detailed tracking of pollution plumes suggests that it splits into two pollution filaments when crossing over northeastern China. One of them is mixed with freshly emitted pollutants, with significant photochemical production of ozone, but the other one follows a rather constant evolution of the $\mathrm{O}_{3}$-to-CO enhancement ratio until reaching the Pacific.

The present satellite-based approach has shown original and air-quality-relevant skills to describe the evolution of transboundary pollution outbreaks across East Asia. Particularly, distinguishing photochemical production during transport to that originally produced over major pollution sources is a significant contribution to a better understanding of air quality degradation and developing efficient pollution mitigation policies. Future studies will extend the approach to longer time periods and consider multiple meteorological regimes propitious for East Asian pollution.

Data availability. Satellite observations of lowermost tropospheric ozone from the IASI + GOME2 multispectral approach in 2009 and 2010 used here can be provided upon request to Juan Cuesta from the LISA laboratory (cuesta@ lisa.u-pec.fr). From 2017, global IASI + GOME2 ozone retrievals are freely available at the AERIS data centre at http://www.aeris-data.fr. Chemistry-transport simulations with the CHASER model globally and with the WRFChem model over Asia used here may be requested from the JAMSTEC Institute (Kazuyuki Miyazaki, kmiyazaki@jamstec.go.jp for CHASER; Masayuki Takigawa, takigawa@jamstec.go.jp for WRFChem). In situ measurements of surface ozone over Fukue Island may be requested from JAMSTEC Institute (Yugo Kanaya, yugo@jamstec.go.jp).

Competing interests. The authors declare that they have no conflict of interest.

Special issue statement. This article is part of the special issue "Quadrennial Ozone Symposium 2016 - Status and trends of atmospheric ozone (ACP/AMT inter-journal SI)". It is a result of the Quadrennial Ozone Symposium 2016, Edinburgh, United Kingdom, 4-9 September 2016.

Acknowledgements. Authors are grateful for the essential support of the Sakura Hubert Curien Partnership (PHC) for this FrenchJapanese cooperative study of ozone pollution over East Asia. This programme is supported by the Japan Society for the Promotion of Science (JSPS) and the Ministère des affaires étrangères et du développement international (MAEDI) and the Ministère de l'Éducation Nationale, de l'Enseignement Supérieur et de la Recherche (MENESR), and the French Embassy in Japan. We thank the financial support of the Centre National des Etudes Spatiales (CNES, the French Space Agency) via the "SURVEYOZON" project from TOSCA (Terre Ocean Surface Continentale Atmosphère), the Programme National de Télédétection Spatiale (PNTS, www.insu.cnrs.fr/pnts, grant PNTS-2013-05, project "SYNAEROZON"), the PolEASIA project (ANR-15-CE04-0005) from the Agence Nationale de la Recherche (ANR), the Université Paris Est Créteil (UPEC) and the Centre National des Recherches Scientifiques-Institut National des Sciences de l'Univers (CNRSINSU) for making this research work and its publication possible.

We warmly acknowledge all datasets provided for this study: CO satellite retrievals from IASI from ULB/LATMOS (Université Libre de Bruxelles/Laboratoire Atmosphères, Milieux, Observations Spatiales) laboratories (special thanks to C. Clerbaux and J. Hadji-Lazaro), IASI data and support in the production of IASI + GOME2 from the French atmospheric data centre AERIS (www.aeris-data.fr; special thanks to C. Boonne), tropospheric $\mathrm{NO}_{2}$ column data and $\mathrm{CH}_{2} \mathrm{O}$ from the GOME-2 and OMI sensors respectively from TEMIS (www.temis.nl) and BIRA-IASB (h2co.aeronomie.be), GOME-2 Level 1 data from EUMETSAT (provided by the NOAA CLASS data portal), WRF-CMAQ 
simulations from Prof. K. Yamaji from the University of Kobe, ozonesondes data from WOUDC/SHADOZ/GMD (World Ozone and Ultraviolet Data Centre/Southern Hemisphere Additional Ozonesondes/Global Monitoring Division) networks, surface in situ measurements of ozone from the GAW/EANET (Global Atmosphere Watch/Acid Deposition Monitoring Network in East Asia) networks and meteorological reanalysis (ESPRI ClimServ centre for providing access to data) from ECMWF. IASI is a joint mission of EUMETSAT and CNES. The authors gratefully acknowledge the NOAA Air Resources Laboratory (ARL) for the provision of the HYSPLIT transport and dispersion model and/or READY website (http://www.ready.noaa.gov) used in this publication. We acknowledge the Institut für Meteorologie und Klimaforschung (Germany) and RT Solutions (USA) for licences to use respectively the KOPRA and VLIDORT radiative transfer models. We also thank Z. Cai from the Chinese Academy of Sciences (China) and X. Liu from Harvard-Smithsonian Center for Astrophysics (USA) for their support in producing IASI + GOME2 data and fruitful discussions, and C. Caumont from LISA for contributing to the validation of IASI + GOME2 data.

Edited by: Stefan Reis

Reviewed by: two anonymous referees

\section{References}

Akimoto, H., Mori, Y., Sasaki, K., Nakanishi, H., Ohizumi, T., and Itano, Y.: Analysis of monitoring data of ground-level ozone in Japan for long-term trend during 1990-2010: Causes of temporal and spatial variation, Atmos. Environ., 102, 302-310, 2015.

Boersma, K. F., Eskes, H. J., and Brinksma, E. J.: Error Analysis for Tropospheric $\mathrm{NO}_{2}$ Retrieval from Space, J. Geophys. Res., 109, D04311, https://doi.org/10.1029/2003JD003962, 2004.

Boersma, K. F., Eskes, H. J., Dirksen, R. J., van der A, R. J., Veefkind, J. P., Stammes, P., Huijnen, V., Kleipool, Q. L., Sneep, M., Claas, J., Leitão, J., Richter, A., Zhou, Y., and Brunner, D.: An improved tropospheric $\mathrm{NO}_{2}$ column retrieval algorithm for the Ozone Monitoring Instrument, Atmos. Meas. Tech., 4, 19051928, https://doi.org/10.5194/amt-4-1905-2011, 2011.

Cai, Z., Liu, Y., Liu, X., Chance, K., Nowlan, C. R., Lang, R., Munro, R., and Suleiman, R.: Characterization and correction of Global Ozone Monitoring Experiment 2 ultraviolet measurements and application to ozone profile retrievals, J. Geophys. Res., 117, D07305, https://doi.org/10.1029/2011JD017096, 2012.

Chai, F., Gao, J., Chen, Z., Wang, S., Zhang, Y., Zhang, J., and Ren, C.: Spatial and temporal variation of particulate matter and gaseous pollutants in 26 cities in China, J. Environ. Sci., 26, 75$82,2014$.

Chin, M., Jacob, D. J., Munger, J. W., Parrish, D. D., and Doddridge, B. G.: Relationship of ozone and carbon monoxide over North America, J. Geophys. Res.-Atmos., 99, 14565-14573, 1994.

Clerbaux, C., Coheur, P. F., Hurtmans, D., Barret, B., Carleer, M., Colin, R., Semeniuk, K., McConnell, J. C., Boone, C., and Bernath, P.: Carbon monoxide distribution from the ACE-FTS solar occultation measurements, Geophys. Res. Lett., 32, 1-4, https://doi.org/10.1029/2005GL022394, 2005.
Clerbaux, C., Boynard, A., Clarisse, L., George, M., Hadji-Lazaro, J., Herbin, H., Hurtmans, D., Pommier, M., Razavi, A., Turquety, S., Wespes, C., and Coheur, P.-F.: Monitoring of atmospheric composition using the thermal infrared IASI/MetOp sounder, Atmos. Chem. Phys., 9, 6041-6054, https://doi.org/10.5194/acp-96041-2009, 2009.

Cooper, O. R., Moody, J. L., Parrish, D. D., Trainer, M., Ryerson, T. B., Holloway, J. S., Hübler, G., Fehsenfeld, F. C., and Evans, M. J.: Trace gas composition of midlatitude cyclones over the western North Atlantic Ocean: A conceptual model, J. Geophys. Res., 107, 4056, https://doi.org/10.1029/2001JD000901, 2002.

Cuesta, J., Eremenko, M., Liu, X., Dufour, G., Cai, Z., Höpfner, M., von Clarmann, T., Sellitto, P., Foret, G., Gaubert, B., Beekmann, M., Orphal, J., Chance, K., Spurr, R., and Flaud, J.-M.: Satellite observation of lowermost tropospheric ozone by multispectral synergism of IASI thermal infrared and GOME-2 ultraviolet measurements over Europe, Atmos. Chem. Phys., 13, 9675-9693, https://doi.org/10.5194/acp-13-9675-2013, 2013.

De Smedt, I., Müller, J.-F., Stavrakou, T., van der A, R., Eskes, H., and Van Roozendael, M.: Twelve years of global observations of formaldehyde in the troposphere using GOME and SCIAMACHY sensors, Atmos. Chem. Phys., 8, 4947-4963, https://doi.org/10.5194/acp-8-4947-2008, 2008.

De Wachter, E., Barret, B., Le Flochmoën, E., Pavelin, E., Matricardi, M., Clerbaux, C., Hadji-Lazaro, J., George, M., Hurtmans, D., Coheur, P.-F., Nedelec, P., and Cammas, J. P.: Retrieval of MetOp-A/IASI CO profiles and validation with MOZAIC data, Atmos. Meas. Tech., 5, 2843-2857, https://doi.org/10.5194/amt5-2843-2012, 2012.

Dee, D. P., Uppala, S. M., Simmons, A. J., Berrisford, P., Poli, P., Kobayashi, S., and Bechtold, P.: The ERA-Interim reanalysis: Configuration and performance of the data assimilation system, Q. J. Roy. Meteor. Soc., 137, 553-597, https://doi.org/10.1002/qj.828, 2011.

Dentener, F., Keating, T., and Akimoto, H.: Hemispheric Transport of Air Pollution, Air Pollution studies $\mathrm{n}^{\circ}$ 17, ISBN 978-92-1117043-6, Geneva, 2010.

Deshler, T., Mercer, J. L., Smit, H. G. J., Stubi, R., Levrat, G., Johnson, B. J., Oltmans, S. J., Kivi, R., Thompson, A. M., Witte, J., Davies, J., Schmidlin, F. J., Brothers, G., and Sasaki, T.: Atmospheric comparison of electrochemical cell ozonesondes from different manufacturers, and with different cathode solution strengths: The Balloon Experiment on Standards for Ozonesondes, J. Geophys. Res., 113, D04307, https://doi.org/10.1029/2007JD008975, 2008.

Ding, A., Wang, T., Xue, L., Gao, J., Stohl, A., Lei, H., Jin, D., Ren, Y., Wang, X., Wei, X., Qi, Y., Liu, J., and Zhang, X.: Transport of north China air pollution by midlatitude cyclones: Case study of aircraft measurements in summer 2007, J. Geophys. Res., 114, D08304, https://doi.org/10.1029/2008JD011023, 2009.

Dufour, G., Eremenko, M., Griesfeller, A., Barret, B., LeFlochmoën, E., Clerbaux, C., Hadji-Lazaro, J., Coheur, P.-F., and Hurtmans, D.: Validation of three different scientific ozone products retrieved from IASI spectra using ozonesondes, Atmos. Meas. Tech., 5, 611-630, https://doi.org/10.5194/amt-5611-2012, 2012. 
Dufour, G., Eremenko, M., Cuesta, J., Doche, C., Foret, G., Beekmann, M., Cheiney, A., Wang, Y., Cai, Z., Liu, Y., Takigawa, M., Kanaya, Y., and Flaud, J.-M.: Springtime daily variations in lower-tropospheric ozone over east Asia: the role of cyclonic activity and pollution as observed from space with IASI, Atmos. Chem. Phys., 15, 10839-10856, https://doi.org/10.5194/acp-1510839-2015, 2015.

Eremenko, M., Dufour, G., Foret, G., Keim, C., Orphal, J., Beekmann, M., Bergametti, G., and Flaud, J.-M.: Tropospheric ozone distributions over Europe during the heat wave in July 2007 observed from infrared nadir spectra recorded by IASI, Geophys. Res. Lett., 35, L18805, https://doi.org/10.1029/2008GL034803, 2008.

European Organisation for the Exploitation of Meteorological Satellites (EUMETSAT): GOME-2 Level 1 product generation specification, EPS.SYS.SPE.990011, Darmstadt, Germany, 2006.

Foret, G., Eremenko, M., Cuesta, J., Sellitto, P., Barré, J., Gaubert, B., Coman, A., Dauphin, P., Beekmann, M., and Dufour, G.: Ozone pollution: What do we see from space?, A case study, J. Geophys. Res.-Atmos., 119, 8476-8499, https://doi.org/10.1002/2013JD021340, 2014.

Fu, D., Worden, J. R., Liu, X., Kulawik, S. S., Bowman, K. W., and Natraj, V.: Characterization of ozone profiles derived from Aura TES and OMI radiances, Atmos. Chem. Phys., 13, 3445-3462, https://doi.org/10.5194/acp-13-3445-2013, 2013.

Fu, D., Bowman, K. W., Worden, H. M., Natraj, V., Worden, J. R., Yu, S., Veefkind, P., Aben, I., Landgraf, J., Strow, L., and Han, Y.: High-resolution tropospheric carbon monoxide profiles retrieved from CrIS and TROPOMI, Atmos. Meas. Tech., 9, 2567-2579, https://doi.org/10.5194/amt-9-2567-2016, 2016.

Gao, J., Wang, T., Ding, A., and Liu, C.: Observational study of ozone and carbon monoxide at the summit of mount Tai (1534 ma.s.1.) in central-eastern China, Atmos. Environ., 39, 4779-4791, 2005.

George, M., Clerbaux, C., Hurtmans, D., Turquety, S., Coheur, P.F., Pommier, M., Hadji-Lazaro, J., Edwards, D. P., Worden, H., Luo, M., Rinsland, C., and McMillan, W.: Carbon monoxide distributions from the IASI/METOP mission: evaluation with other space-borne remote sensors, Atmos. Chem. Phys., 9, 8317-8330, https://doi.org/10.5194/acp-9-8317-2009, 2009.

Grell, G. A., Peckham, S. E., Schmitz, R., McKeen, S. A., Frost, G., Skamarock, W. C., and Eder, B.: Fully coupled "online" chemistry within the WRF model, Atmos. Environ., 39, 6957-6975, 2005.

Guenther, A., Zimmerman, P. R., Harley, P., Monson, R. K., and Fall, R.: Isoprene and monoterepene emission rate variability: Model evaluations and sensitivity analyses, J. Geophys. Res., 98, 12609-12617, 1993.

Guenther, A., Hewitt, C. N., Erickson, D., Fall, R., Geron, C., Graedel, T., Harley, P., Klinger, L., Lerdau, M., McKay, W., Pierce, T., Scholes, B., Steinbrecher, R., Tallamraju, R., Taylor, J., and Zimmerman, P.: A global model of natural volatile organic compound emissions, J. Geophys. Res., 100, 8873-8892, https://doi.org/10.1029/94JD02950, 1995.

Hauglustaine, D. A., Hourdin, F., Jourdain, L., Filiberti, M. A., Walters, S., Lamarque, J. F., and Holland, E. A.: Interactive chemistry in the Laboratoire de Météorologie Dynamique general circulation model: Description and background tropo- spheric chemistry evaluation, J. Geophys. Res., 109, D04314, https://doi.org/10.1029/2003JD003957, 2004.

Hayashida, S., Liu, X., Ono, A., Yang, K., and Chance, K.: Observation of ozone enhancement in the lower troposphere over East Asia from a space-borne ultraviolet spectrometer, Atmos. Chem. Phys., 15, 9865-9881, https://doi.org/10.5194/acp-159865-2015, 2015.

Hunt, B. R., Kostelich, E. J., and Szunyogh, I.: Efficient data assimilation for spatiotemporal chaos: a local ensemble transform Kalman filter, Physica D, 230, 112-126, 2007.

Hurtmans, D., Coheur, P. F., Wespes, C., Clarisse, L., Scharf, O., Clerbaux, C., Hadji-Lazaro, J., George, M., and Turquety, S.: FORLI radiative transfer and retrieval code for IASI, J. Quant. Spectrosc. Ra., 113, 1391-1408, 2012.

Kanamitsu, M., Ebisuzaki, W., Woollen, J., Yang, S. K., Hnilo, J. J., Fiorino, M., and Potter, G. L.: NCEP-DOE AMIP-II reanalysis (R-2), B. Am. Meteorol. Soc., 83, 1631-1643, https://doi.org/10.1175/BAMS-83-11-1631, 2002.

Kanaya, Y., Tanimoto, H., Yokouchi, Y., Taketani, F., Komazaki, Y., Irie, H., Takashima, H., Pan, X., Nozoe, S., and Inomata, S.: Diagnosis of Photochemical Ozone Production Rates and Limiting Factors in Continental Outflow Air Masses Reaching Fukue Island, Japan: Ozone-Control Implications, Aerosol Air Qual. Res., 16, 430-441, 2016.

Kannari, A., Tonooka, Y., Bada, T., and Murano, K.: Development of multiple-species $1 \mathrm{~km} \times 1 \mathrm{~km}$ resolution hourly basis emissions inventory for Japan, Atmos. Environ., 41, 3428-3439, https://doi.org/10.1016/j.atmosenv.2006.12.015, 2007.

Keim, C., Eremenko, M., Orphal, J., Dufour, G., Flaud, J.-M., Höpfner, M., Boynard, A., Clerbaux, C., Payan, S., Coheur, P.F., Hurtmans, D., Claude, H., Dier, H., Johnson, B., Kelder, H., Kivi, R., Koide, T., López Bartolomé, M., Lambkin, K., Moore, D., Schmidlin, F. J., and Stübi, R.: Tropospheric ozone from IASI: comparison of different inversion algorithms and validation with ozone sondes in the northern middle latitudes, Atmos. Chem. Phys., 9, 9329-9347, https://doi.org/10.5194/acp-9-93292009, 2009.

Kerzenmacher, T., Dils, B., Kumps, N., Blumenstock, T., Clerbaux, C., Coheur, P.-F., Demoulin, P., García, O., George, M., Griffith, D. W. T., Hase, F., Hadji-Lazaro, J., Hurtmans, D., Jones, N., Mahieu, E., Notholt, J., Paton-Walsh, C., Raffalski, U., Ridder, T., Schneider, M., Servais, C., and De Mazière, M.: Validation of IASI FORLI carbon monoxide retrievals using FTIR data from NDACC, Atmos. Meas. Tech., 5, 2751-2761, https://doi.org/10.5194/amt-5-2751-2012, 2012.

Kim, P. S., Jacob, D. J., Liu, X., Warner, J. X., Yang, K., Chance, K., Thouret, V., and Nedelec, P.: Global ozone-CO correlations from OMI and AIRS: constraints on tropospheric ozone sources, Atmos. Chem. Phys., 13, 9321-9335, https://doi.org/10.5194/acp13-9321-2013, 2013.

Koelemeijer, R., Stammes, P., Hovenier, J., and Haan, J. D.: A fast method for retrieval of cloud parameters using oxygen A band measurements from the Global Ozone Monitoring Experiment, J. Geophys. Res., 106, 3475-3490, https://doi.org/10.1029/2000JD900657, 2001.

Lelieveld, J., Evans, J. S., Fnais, M., Giannadaki, D., and Pozzer, A.: The contribution of outdoor air pollution sources to premature mortality on a global scale, Nature, 525, 367-371, 2015. 
Levelt, P. F., van den Oord, G. H. J., Dobber, M. R., Mälkki, A., Visser, H., de Vries, J., Stammes, P., Lundell, J., and Saari, H.: The Ozone Monitoring Instrument, IEEE T. Geosci. Remote, 44, 1093-1101, 2006.

Lin, M., Holloway, T., Carmichael, G. R., and Fiore, A. M.: Quantifying pollution inflow and outflow over East Asia in spring with regional and global models, Atmos. Chem. Phys., 10, 42214239, https://doi.org/10.5194/acp-10-4221-2010, 2010.

Liu, X., Bhartia, P. K., Chance, K., Spurr, R. J. D., and Kurosu, T. P.: Ozone profile retrievals from the Ozone Monitoring Instrument, Atmos. Chem. Phys., 10, 2521-2537, https://doi.org/10.5194/acp-10-2521-2010, 2010.

Logan, J. A., Prather, M. J., Wofsy, S. C., and McElroy, M. B.: Tropospheric chemistry: A global perspective, J. Geophys. Res.Oceans, 86, 7210-7254, 1981.

Lu, Z., Zhang, Q., and Streets, D. G.: Sulfur dioxide and primary carbonaceous aerosol emissions in China and India, 1996-2010, Atmos. Chem. Phys., 11, 9839-9864, https://doi.org/10.5194/acp-11-9839-2011, 2011.

Mauzerall, D. L., Narita, D., Akimoto, H., Horowitz, L., Walters, S., Hauglustaine, D. A., and Brasseur, G.: Seasonal characteristics of tropospheric ozone production and mixing ratios over East Asia: A global three-dimensional chemical transport model analysis, J. Geophys. Res.-Atmos., 105, 17895-17910, 2000.

McPeters, R. D., Labow, G. J., and Logan, J. A.: Ozone climatological profiles for satellite retrieval algorithms, J. Geophys. Res., 112, D05308, https://doi.org/10.1029/2005JD006823, 2007.

Miyazaki, K., Eskes, H. J., Sudo, K., Takigawa, M., van Weele, M., and Boersma, K. F.: Simultaneous assimilation of satellite $\mathrm{NO}_{2}$, $\mathrm{O}_{3}, \mathrm{CO}$, and $\mathrm{HNO}_{3}$ data for the analysis of tropospheric chemical composition and emissions, Atmos. Chem. Phys., 12, 95459579, https://doi.org/10.5194/acp-12-9545-2012, 2012.

Miyazaki, K., Eskes, H. J., and Sudo, K.: A tropospheric chemistry reanalysis for the years 2005-2012 based on an assimilation of OMI, MLS, TES, and MOPITT satellite data, Atmos. Chem. Phys., 15, 8315-8348, https://doi.org/10.5194/acp15-8315-2015, 2015.

Ohara, T., Akimoto, H., Kurokawa, J., Horii, N., Yamaji, K., Yan, X., and Hayasaka, T.: An Asian emission inventory of anthropogenic emission sources for the period 1980-2020, Atmos. Chem. Phys., 7, 4419-4444, https://doi.org/10.5194/acp-7-44192007, 2007.

Olivier, J. G. J., Bouwman, A. F., Van der Maas, C. W. M., Berdowski, J. J. M., Veldt, C., Bloos, J. P. J., Visschedijk, A. J. H., Zandveld, P. Y. J., and Haverlag, J. L.: Description of EDGAR Version 2.0. A set of global emission inventories of greenhouse gases and ozonedepleting substances for all anthropogenic and most natural sources on a per country basis and on $1^{\circ} \times 1^{\circ}$ grid. RIVM/TNO rep., number 711060002, 1006, RIVM, Bilthoven, 1996.

Olivier, J. G. J., Van Aardenne, J. A., Dentener, F., Ganzeveld, L., and Peters, J. A. H. W.: Recent trends in global greenhouse gas emissions: regional trends 1970-2000 and spatial distribution of key sources in 2000, Environm. Sci., 2, 81-99, 2005.

Parrish, D. D., Holloway, J. S., Trainer, M., Murphy, P. C., Forbes, G. L., and Fehsenfeld, F. C., Export of North American ozone pollution to the north Atlantic Ocean, Science, 259, 1436-1440, 1993.
Price, H. U., Jaffe, D. A., Cooper, O. R., and Doskey, P. V.: Photochemistry, ozone production, and dilution during long-range transport episodes from Eurasia to the northwest United States, J. Geophys. Res., 109, D23S13, https://doi.org/10.1029/2003JD004400, 2004.

Randerson, J. T., van der Werf, G. R., Giglio, L., Collatz, G. J., and Kasibhatla, P. S.: Global Fire Emissions Database, Version 2 (GFEDv2.1), Data Set, available at: http://daac.ornl.gov/, last access: June 2017, 2007.

Richter, A., Burrows, J. P., Nusz, H., Granier, C., and Niemeier, U.: Increase in tropospheric nitrogen dioxide over China observed from space, Nature, 437, 129-132, https://doi.org/10.1038/nature04092, 2005.

Rolph, G., Stein, A., and Stunder, B.: Real-time Environmental Applications and Display sYstem: READY, Environ. Modell. Softw., 95, 210-228, https://doi.org/10.1016/j.envsoft.2017.06.025, 2017.

Sekiya, T. and Sudo, K.: Roles of transport and chemistry processes in global ozone change on interannual and multidecadal time scales, J. Geophys. Res., 119, 4903-4921, https://doi.org/10.1002/2013JD020838, 2014.

Sekiya, T., Miyazaki, K., Ogochi, K., Sudo, K., and Takigawa, M.: Global high-resolution simulations of tropospheric nitrogen dioxide using CHASER V4.0, Geosci. Model Dev., 11, 959-988, https://doi.org/10.5194/gmd-11-959-2018, 2018.

Spurr, R. J. D.: VLIDORT: A linearized pseudo-spherical vector discrete ordinate radiative transfer code for forward model and retrieval studies in multilayer multiple scattering media, J. Quant. Spectrosc. Ra., 102, 316-342, https://doi.org/10.1016/j.jqsrt.2006.05.005, 2006.

Stein, A. F., Draxler, R. R., Rolph, G. D., Stunder, B. J. B., Cohen, M. D., and Ngan, F.: NOAA's HYSPLIT atmospheric transport and dispersion modeling system, B. Am. Meteorol. Soc., 96, 2059-2077, https://doi.org/10.1175/BAMS-D-1400110.1, 2015.

Stiller, G. P., von Clarmann, T., Funke, B., Glatthor, N., Hase, F., Höpfner, M., and Linden, A.: Sensitivity of trace gas abundances retrievals from infrared limb emission spectra to simplifying approximations in radiative transfer modelling, J. Quant. Spectrosc. Ra., 72, 249-280, https://doi.org/10.1016/S00224073(01)00123-6, 2002.

Sudo, K. and Akimoto, H.: Global source attribution of tropospheric ozone: Long-range transport from various source regions, J. Geophys. Res., 112, D12302, https://doi.org/10.1029/2006JD007992, 2007.

Sudo, K., Takahashi, M., Kurokawa, J., and Akimoto, H.: CHASER: A global chemical model of the troposphere. 1. Model description, J. Geophys. Res., 107, 4339, https://doi.org/10.1029/2001JD001113, 2002.

Takigawa, M., Niwano, M., Akimoto, H., and Takahashi, M.: Development of a One-way Nested Global-regional Air Quality Forecasting Model, SOLA, 3, 081-084, https://doi.org/10.2151/sola.2007-021, 2007.

Tikhonov, A.: On the solution of incorrectly stated problems and a method of regularization, Dokl. Akad. Nauk. SSSR+, 151, 501504, 1963.

Verstraeten, W. W., Neu, J. L., Williams, J. E., Bowman, K. W., Worden, J. R., and Boersma, K. F.: Rapid increases in tropo- 
spheric ozone production and export from China, Nat. Geosci., 8, 690-695, 2015.

Wang, R., Tao, S., Ciais, P., Shen, H. Z., Huang, Y., Chen, H., Shen, G. F., Wang, B., Li, W., Zhang, Y. Y., Lu, Y., Zhu, D., Chen, Y. C., Liu, X. P., Wang, W. T., Wang, X. L., Liu, W. X., Li, B. G., and Piao, S. L.: High-resolution mapping of combustion processes and implications for $\mathrm{CO}_{2}$ emissions, Atmos. Chem. Phys., 13, 5189-5203, https://doi.org/10.5194/acp-13-5189-2013, 2013.

Wang, L. T., Wei, Z., Yang, J., Zhang, Y., Zhang, F. F., Su, J., Meng, C. C., and Zhang, Q.: The 2013 severe haze over southern Hebei, China: model evaluation, source apportionment, and policy implications, Atmos. Chem. Phys., 14, 3151-3173, https://doi.org/10.5194/acp-14-3151-2014, 2014.

Wang, M., Shao, M., Chen, W., Lu, S., Liu, Y., Yuan, B., Zhang, Q., Zhang, Q., Chang, C.-C., Wang, B., Zeng, L., Hu, M., Yang, Y., and $\mathrm{Li}$, Y.: Trends of non-methane hydrocarbons (NMHC) emissions in Beijing during 2002-2013, Atmos. Chem. Phys., 15, 1489-1502, https://doi.org/10.5194/acp-15-1489-2015, 2015.

Worden, H. M., Logan, J. A., Worden, J. R., Beer, R., Bowman, K., Clough, S. A., Eldering, A., Fisher, B. M., Gunson, M. R., Herman, R. L., Kulawik, S. S., Lampel, M. C., Luo, M., Magretskaia, I. A., Osterman, G. B., and Shephard, M. W.: Comparisons of Tropospheric Emission Spectrometer (TES) ozone profiles to ozonesondes: Methods and initial results, J. Geophys. Res., 112, D03309, https://doi.org/10.1029/2006JD007258, 2007.
Worden, H. M., Deeter, M. N., Edwards, D. P., Gille, J. C., Drummond, J. R., and Neìdeìlec, P. P., Observations of near-surface carbon monoxide from space using MOPITT multi-spectral retrievals, J. Geophys. Res., 115, D18314, https://doi.org/10.1029/2010JD014242, 2010.

Worden, H. M., Deeter, M. N., Frankenberg, C., George, M., Nichitiu, F., Worden, J., Aben, I., Bowman, K. W., Clerbaux, C., Coheur, P. F., de Laat, A. T. J., Detweiler, R., Drummond, J. R., Edwards, D. P., Gille, J. C., Hurtmans, D., Luo, M., Martínez-Alonso, S., Massie, S., Pfister, G., and Warner, J. X.: Decadal record of satellite carbon monoxide observations, Atmos. Chem. Phys., 13, 837-850, https://doi.org/10.5194/acp-13837-2013, 2013

World Health Organization (WHO): Ambient air pollution: A global assessment of exposure and burden of disease, ISBN 9789241511353, 2016

Zhang, L., Jacob, D. J., Bowman, K. W., Logan, J. A., Turquety, S., Hudman, R. C., and Rinsland, C. P.: Ozone-CO correlations determined by the TES satellite instrument in continental outflow regions, Geophys. Res. Lett., 33, L18804, https://doi.org/10.1029/2006GL026399, 2006.

Zhou, D. K., Larar, A. M., Liu, X., Smith, W. L., Strow, L. L., Yang, P., Schlussel, P., and Calbet, X.: Global land surface emissivity retrieved from satellite ultraspectral IR measurements, Geosci. Rem. Sens. IEEE Trans., 49, 1277-1290, 2011. 